\title{
An Overview of Economic, Legal, and Water Availability Factors Affecting the Demand for Dry and Wet/Dry Cooling for Thermal Power Plants
}

by

Paul L. Hendrickson

June 1977

Prepared for the Energy Research and Development Administration under Contract EY-76-C-06-1830 
NOTICE

This report was prepared as an account of work sponsored by the United States Government. Neither the United States nor the Energy Research and Development Administration, nor any of their employees, nor any of their contractors, subcontractors, or their employees, makes any warranty, exoress or implied, or assumes any legai liability or responsibility for the accuracy, completeness or usefulness of any information, epparatus, product or process disclosed, or represents that its use would not infringe privately owned rights.

\author{
PACIFIC NORTHWEST LABORATORY \\ operated by \\ BATTELLE \\ for the \\ ENERCY RESEARCH AND DEVELOPMENT ADMINISTRATION \\ Under Contract EY-76-C-06-7830
}

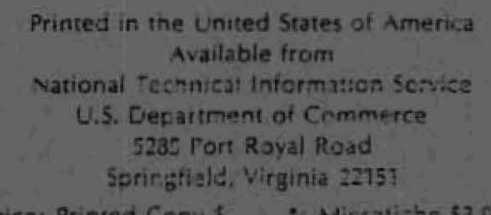

Price: Printed Copy $\therefore$ Mictuliche 5300

\begin{tabular}{|c|c|}
\hline *Pages & Selling Prico \\
\hline $901-625$ & 54.50 \\
\hline $026-050$ & 55.00 \\
\hline $05 i-075$ & 55.50 \\
\hline $076-100$ & 36.00 \\
\hline 101.125 & 56.50 \\
\hline $126-150$ & 57.09 \\
\hline 151.175 & 57.73 \\
\hline $170 \cdot 200$ & $\$ 8.50$ \\
\hline 201.225 & 58.75 \\
\hline $226-250$ & 59.00 \\
\hline $257-275$ & $\$ \pi 0.00$ \\
\hline $27 E \cdot 100$ & $\$ 10.25$ \\
\hline
\end{tabular}


AN OVERVIEN OF ECONOMIC, LEGAL, AND WATER AVAILABILITY FACTORS AFFECTING THE DEMAND FOR DRY AND WET/DRY COOLING FOR THERMAL POWER PLANTS

by

Paul L. Hendrickson

June 1977

BATTELLE

Pacific Northwest Laboratories

P. 0. Box 999

Richland, Washington 99352 


\section{FOREWORD}

The Dry Cooling Tower Development Program at Battelle, Pacific Northwest Laboratory was initiated with a program scope that included the following near-term and ultimate emphases.

Near Term Objectives:

- Develop economic and performance models for cost optimization of total heat rejection systems using dry cooling.

- Analyses of, and dissemination of experience on, existing dry-cooled plant performance.

- Demonstrate certain features of existing technology equipment to provide confidence for specification by utilities.

Uitimate Objective:

- Promote water conservation through industry use of dry cooling by developing and demonstrating the reliability of lower-cost systems. The development of advanced wet/dry systems is also considered to be within this scope.

Over the past two years the following documents have been issued, reporting the results of the work toward these objectives.

Cost Optimization of Dry-Cooled Heat Rejection Systems:

A REVIEW AND ASSESSMENT OF ENGINEERING ECONOMIC STUDIES OF DRY COOLED ELECTRICAL GENERATING PLANTS. B. C. Fryer, BNWL-1976, March 1976.

HEAT TRANSFER AND PRESSURE DROP CHARACTERISTICS OF DRY TOWER EXTENDED SURFACES. PART I: HEAT TRANSFER AND PRESSURE DROP DATA. PFR Engineering Systems, Inc., PFR 7-100, March 1976.

HEAT TRANSFER AND PRESSURE DROP CHARACTERISTICS OF DRY TOWER EXTENDED SURFACES. PART II : DATA ANALYS IS AND CORRELATION. PFR Engineering Systems, Inc., PFR 7-102, June 1976. 
Analysis of performance of existing dry-cooled plants:

DRY COOLING TOWER PROGRAM: RESULTS OF INDUSTRIAL CONTACTS THROUGH AUGUST 1974. BINWL-1878, November 1, 1974.

A SURVEY OF MATERIALS AND CORROSION PERFORMANCE IN DRY COOLING APPLICATIONS. A. B. Johnson, Jr. D. R. Pratt, and G. E. Zima, BNWL-1958, March 1976.

EUROPEAN DRY COOLING TOWER OPERATING EXPERIENCE.

J. G. DeSteese and K. Simhan, BNWL-1995, March 1976.

MATHEMATICAL AND EXPERIMENTAL INVESTIGATIONS ON

DISPERS ION AND RECIRCULATION OF PLUMES FROM ORY

COOLING TOWERS AT WYODAK POWER PLANT IN WYOMING.

Y. Onishi and D. S. Trent, BNWL-1982, February 1976.

Advanced dry (wet/dry) cooled systems:

PREL IMINARY EVALUATION OF WET/DRY COOLING CONCEPTS

FOR POWER PLANTS. W. V. LOSCutoff, BNWL-1969 July 1976.

COMPATIBILITY OF AMMONIA WITH CANDIDATE DRY COOLING SYSTEM MATERIALS. D. R. Pratt, BNWL-1992, Apri1 1976.

SCALE FORMATION IN DELUGED DRY COOLING SYSTEMS.

D. R. Pratt, BNWL-2060, March 1976.

AMMONIA AS AN INTERMEDIATE HEAT EXCHANGE FLUID FOR DRY COOLED TOWERS. R. T. ATlemann, B. M. Johnson, and G. C. Smith. BNWL-SA-5997, September 1976.

A group of recently issued reports serves the dual purpose of developing cost optimization models for dry cooling systems based on available technology and comparing the results of analyzing the costs of these systems with the projected cost of several advanced dry and wet/dry systems. Included in this group are:

AN ENGINEER ING AND COST COMPARISON OF THREE DIFFERENT ALL-DRY COOLING SYSTEMS. B. C. Fryer, D. W. Faletti Dan J. Braun, David J. Braun, and L. E. Wiles, BNWL-2121, September 1976. 
A STUDY OF THE COMPARATIVE COSTS OF FIVE WET/DRY COOLING TOWER CONCEPTS. F. R. Zaloudek, R. T. ATTemann, D. W. Faletti, B. M. Johnson, H. L. Parry, G. C. Smith, R. D. Tokarz, and

R. A. Walter, BNWL-2122, September 1976.

DRY COOLING OF POWER GENERATING STATIONS: A SUMMARY

OF THE ECONOMIC EVALUATION OF SEVERAL ADVANCED CONCEPTS

VIA A CESIGN OPTIMIZATION STUDY AND A CONCEPTUAL

DESIGN AND COST ESTIMATE. B. M. Johnson, R. T. Al lemann, D.W. Faletti, B. C. Fryer, and F. R. Zaloudek, BNWL-2120, September 1976.

COSTS AND COST ALGORITHMS FOR DRY COOLING TOWER SYSTEMS. P. A. Ard, C. H. Henager, D. R. Pratt, and L. E. Wiles, BNWL-2123, September 1976.

A USER'S MANUAL FOR THE BNW-I OPTIMIZATION CODE FOR DRY-COOLED POWER PLANTS. David J. Braun, Dan J. Braun, Warren V. DeMier, D.W. Faletti, and L. E. Wiles, BNWL-2180, January 1977.

This report considers the economic, legal, and water availability factors which will contribute to selection of dry and wet/dry cooling vis$a-v$ is other methods of cooling in the future and thus influence the projected market for these types of cooling systems in the next twenty years. 

AN OVERVIEW OF ECONOMIC, LEGAL, AND WATER AVAILABILITY FACTORS AFFECTING THE DEMAND FOR DRY AND WET/DRY COOLING FOR THERMAL POWER PLANTS

\section{SUMMARY}

It appears likely that on the order of 20 GWe of thermal power plant capacity will utilize wet/dry cooling through the year 2000 . The requirement could conceivably be as low as 10 GWe or as high as 45 GWe. The amount of totally dry cooling needed is estimated to be small because of its extraordinary high cost relative to other cooling alternatives. The area with the greatest likelihood for utilizing wet/dry cooling is the Southwest, from California to Texas. This area has the greatest physical shortage of water in the country and thus will likely experience the greatest water allocation pressures.

Where water is available, the optimum economic decision will be to utilize wet cooling. The breakeven point where wet/dry cooling would be selected over totally wet cooling is at a water cost of about $\$ 2.00 / 1000$ gal (1977 dollars). This number is only an approximation and depends upon a great many variables and assumptions. Various water sources are available which can provide water at less than this cost, including conveyance and treatment of agricultural and municipal waste water (about $\$ 1.10 / 1000$ gal) and outright purchase of irrigated farms to acquire water rights $(\$ 0.40$ $0.70 / 1000 \mathrm{ga} 1$ ). Further research on the extent to which these sources are available for cooling seems warranted.

Even though cooling economics favor wet cooling, wet/dry cooling will still be used in certain circumstances for several reasons. In the near term, its principal advantage will be to provide plant location flexibility. A few mine-mouth coal-fired plants will likely utilize dry or wet/dry cooling when transporting the coal to an area with water is more expensive than wet/dry cooling. The Wyodak facility in Wyoming and San Juan III in northwest New Mexico are examples. Wet/dry cooling may be selected (if adequate water is unavailable for wet cooling) in order to locate a power 
plant at a site already occupied by another plant(s). The utility would thus be able to take advantage of existing transmission corridors, avoid creating another boom town, and take advantage of certain economies-of-scale (e.g., reduced exclusion area) and other factors. The San Juan III facility is also an example of this case. Wet/dry cooling could be selected in order to locate a power plant near a load center and thereby reduce transmission line losses. Actual physical water shortage and storage capacity will lead to a limited amount of wet/dry cooling in the southwest. Finally, political considerations will lead to some wet/dry cooling. Most likely these will take the form of restrictions on the transfer of water from agricultural to industrial use.

When free transfer of water rights is permitted, the vast quantity of water used for irrigation (over $80 \%$ of total water consumption in nearly a 11 of the western states) and the fact that water is worth at least five times as much to a utility as to a farmer, will combine to limit the use of wet/dry cooling to isolated cases. However, the California State Water Resources Control Board currently has a policy of not approving the use of inland water for power plant cooling unless the water is sufficiently saline to have little or no agricultural value. Montana prohibits transfer of water rights greater than $15 \mathrm{cfs}$ from agricultural to industrial use. If these types of policies become more restrictive and expand to other states, more than 20 GWe of wet/dry cooling will likely be needed by the year 2000 . No evidence of impending transfer restrictions other than in these two states was found, however. 
CONTENTS

FORENARD • $. \quad . \quad . \quad . \quad . \quad . \quad . \quad . \quad . \quad . \quad . \quad i i$

SUMMARY . . . . . . . . . . . . . . . $v$

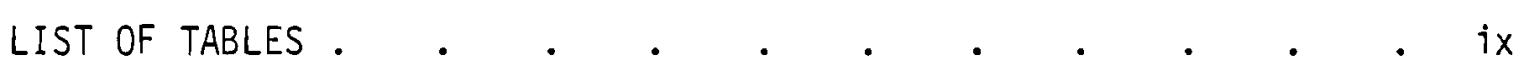

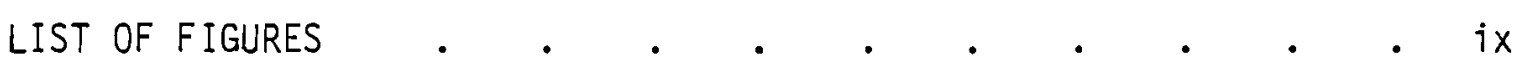

INTRODUCTION

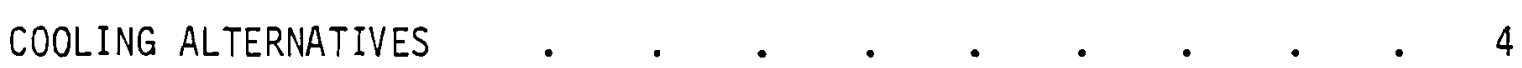

ONCE THROUGH COOLING

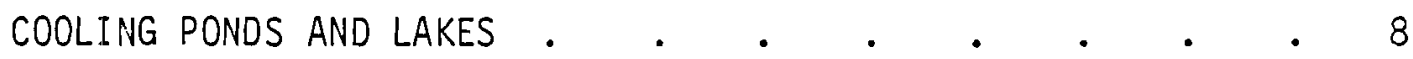

EVAPORATIVE COOLING TOWERS $\quad \cdot \quad \cdot \quad \cdot \quad \cdot \quad \cdot \quad \cdot \quad \cdot \quad \cdot 9$

DRY AND WET/DRY COOLING $\ldots$

ECONOMICS OF COOLING TOWER ALTERNATIVES . . . . . . . 11

RELATIVE COST OF ALTERNATIVES ..$\quad \cdot \quad \cdot \quad \cdot \quad \cdot \quad \cdot 11$

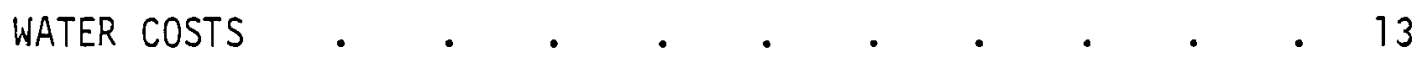

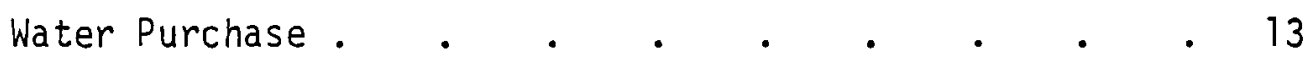

Municipal Waste Water . . . . . . . 14

Agricultural Waste Water. . . . . . . 15

Irrigated Farm Purchase . $. \quad . \quad . \quad . \quad . \quad .15$

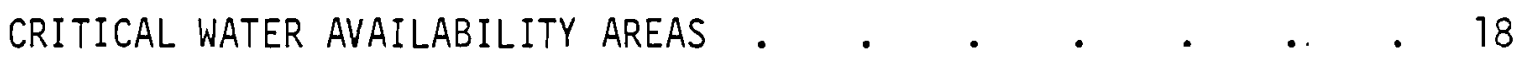

WATER AVAILABILITY AND CONSUMPTION IN THE U.S. $. \cdot . \quad \cdot 18$

REVIEW OF STUDIES ESTIMATING THE DEMAND FOR WET/DRY COOLING . 19

REGIONAL PROJECTIONS OF WATER AVAILABILITY FOR COOLING • • 21

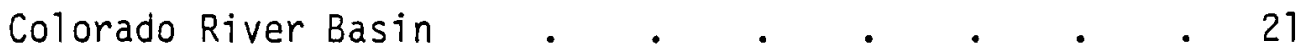

Upper Missouri River Basin . . . . . . 22

California . . . . . . . . . . . 24

ALTERNATIVES FOR ACQUIRING INLAND WATER AND ASSOCIATED DIFFICULTIES 26 APPROPRIATION • EXERCISE OF RIPARIAN RIGHTS • • • • • • ACQUISITION FROM FEDERAL WATER PROJECTS . . . . . 28 


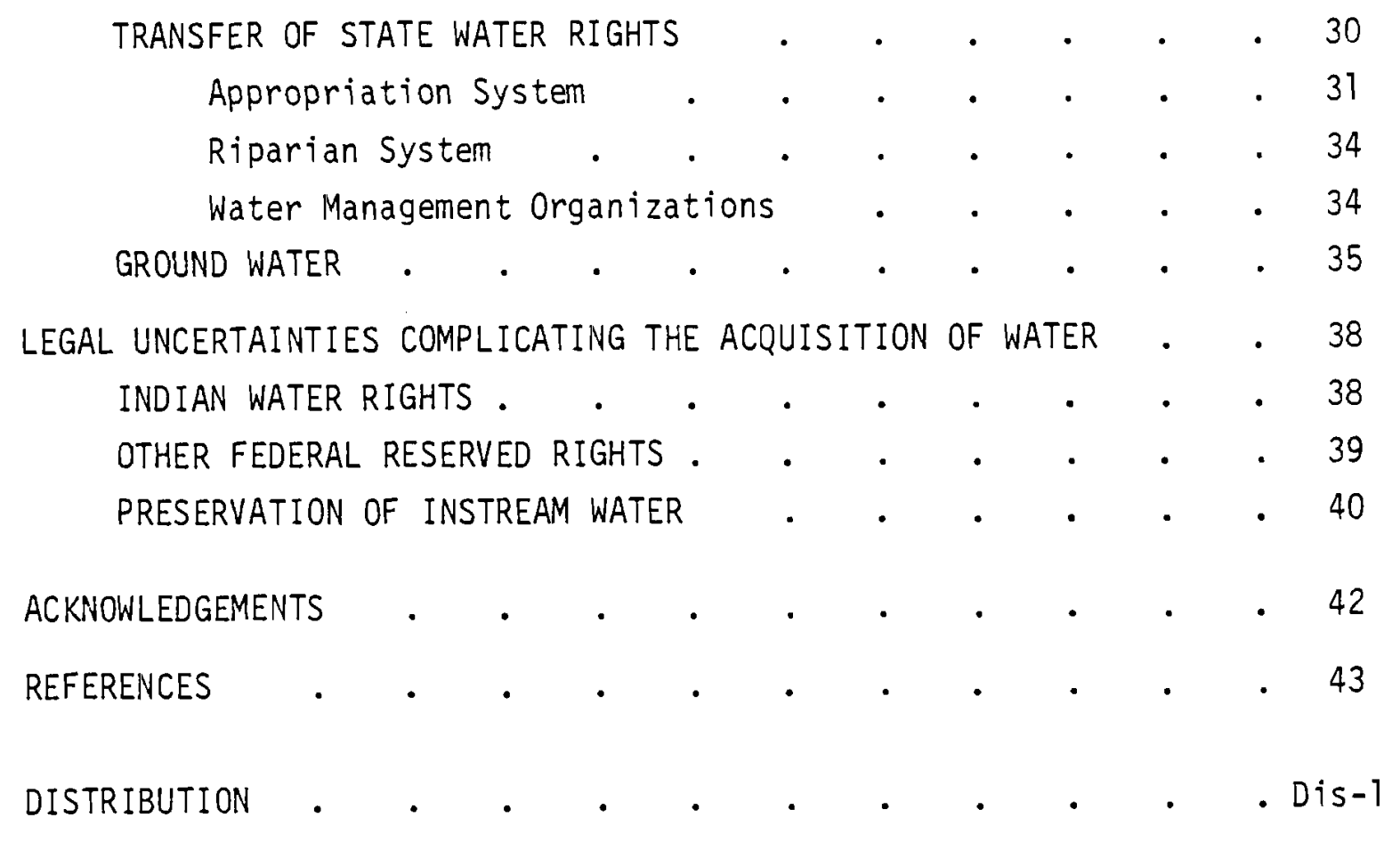

viii 


\section{$\underline{\text { TABLES }}$}

1. STEAM ELECTRIC GENERATING FORECASTS . . . . . . . 2

2. 1970 MIX IN PERCENT (BY CAPACITY) OF COOLING SYSTEM TYPE. • 4

3. TYPICAL WATER CONSUMPTION DATA FOR ALTERNATIVE COOLING MODELS. 5

4. RELATIVE COSTS OF ALTERNATIVE COOLING SYSTEMS FOR NUCLEAR PLANT 6

5. WATER BREAKEVEN COSTS . . . . . . . . . . 11

6. COST OF WATER ACQUIRED BY PURCHASING IRRIGATED FARMS . • 16

7. WATER SUPPLY AND USE IN THE COLORADO RIVER SYSTEM • • • 21

8. RIVER MILEAGE CLASSIFICATION FOR COMPONENTS OF THE NATIONAL WILD AND SCENIC RIVER SYSTEM

\section{FIGURES}

1. UPPER COLORADO RIVER BASIN WATER FOR ENERGY 1974 TO 2000 • 23 
AN OVERVIEW OF ECONOMIC, LEGAL, AND WATER AVAILABILITY FACTORS AFFECTING THE DEMAND FOR DRY AND WET/DRY COOLING FOR THERMAL POWER PLANTS

\section{INTRODUCTION}

The purpose of the study is to identify and discuss some of the important factors which will affect the demand for dry and wet/dry cooling of thermal power plants during the remainder of this century. The paper begins by discussing cooling alternatives and their advantages, disadvantages, and relative costs. Critical water supply geographic areas are identified. Finally, alternatives for acquiring water for cooling and associated legal difficulties are discussed.

Consumption of electricity in the United States continues to increase. A11 forecasts point to further increases through this century, al though the forecasts make varying growth rate assumptions. Two growth scenarios for fossil and nuclear generating capacity are shown in Table 1.

The Utility Water Act Group (UWAG), composed of certain members of the Edison Electric Institute, estimates are based on $7 \%$ annual growth in electric capacity. The Energy Research and Development Administration (ERDA) estimates assume $5 \%$ annual growth. The total generating capability in 2000 ( $1144 \mathrm{GWe}$ ) corresponds closely to the current "Low" growth ERDA projections.

Virtually all existing thermal power plants require air or water as a heat sink to which waste heat can be expelled. There is a strong potential for using some of the waste heat beneficially; however, it appears likely that the major advantage of these uses will be to reduce costs in the alternative applications and to conserve fossil fuels. It is not likely that cooling tower hardware can be eliminated for at least two reasons. First, it is unlikely that all of a plant's waste heat can be beneficially used; second, cooling hardware may be needed in some areas as a back-up.

Beneficial uses of low-grade heat for agricultural, aquaculture, and for other uses are currently being studied. Commercial green houses utilizing 
TABLE 1. Steam-Electric Generating Forecasts (Gigawatts electric, GWe)

\begin{tabular}{|c|c|c|c|c|c|c|c|c|c|c|}
\hline \multirow[b]{2}{*}{ Water Resource Region } & \multicolumn{2}{|c|}{$1970^{3}$} & \multicolumn{2}{|c|}{1983 (UWAG) } & \multicolumn{2}{|c|}{1983 (ERDA) $^{2}$} & \multicolumn{2}{|c|}{2000 (UWAG) $^{3}$} & \multicolumn{2}{|c|}{$2000(E R D A)^{2}$} \\
\hline & Fossil & Nuclear & Fossil & Nuclear & Fossil & Nuclear & Fossil & Nuclear & Fossil & Nuclear \\
\hline 1. New England & 10.6 & 1.4 & 19.4 & 18.7 & 13.9 & 11.4 & 22.6 & 90.5 & 31.6 & 20.5 \\
\hline 2. Mid-Atlantic & 35.1 & 0.61 & 60.4 & 13.1 & 33.2 & 27.4 & 73.2 & 170.9 & 68.1 & 44.1 \\
\hline 3. South Atlantic & 31.4 & - & 77.3 & 38.8 & 42.1 & 34.7 & 137.8 & 413.4 & 153.7 & 99.6 \\
\hline 4. Great Lakes & 25.5 & 1.6 & 62.7 & 13.8 & 27.8 & 22.9 & 78.7 & 118.1 & 54.9 & 35.5 \\
\hline 5. Onio & 43.9 & 0.10 & 101.6 & 22.3 & 45.0 & 37.0 & 127.6 & 191.3 & 88.9 & 57.6 \\
\hline 6. Tennessee & 9.4 & - & 14.3 & 12.0 & 9.5 & 7.9 & 11.7 & 46.9 & 16.4 & 10.6 \\
\hline 7. Upper Mississippi & 18.4 & 1.0 & 31.2 & 17.4 & 17.6 & 14.5 & 55.3 & 102.6 & 44.0 & 28.5 \\
\hline 8. Lower Mississippi & 10.5 & - & 27.9 & 5.7 & 12.2 & 10.0 & 57.5 & 86.2 & 40.0 & 26.0 \\
\hline 9. Souris-Red-Rainy & 0.25 & - & 0.56 & 0.24 & 0.29 & 0.24 & 0.70 & 1.6 & 0.66 & 0.42 \\
\hline 10. Missouri Basin & 8.7 & - & 19.4 & 8.1 & 10.0 & 8.2 & 24.2 & 56.5 & 22.5 & 14.6 \\
\hline 11. Arkansas-White-Red & 10.8 & - & 28.5 & 5.8 & 12.5 & 10.3 & 58.7 & 88.0 & 40.9 & 26.5 \\
\hline 12. Texas-Guif & 20.6 & - & 53.5 & 9.9 & 23.0 & 19.0 & 81.9 & 122.8 & 57.1 & 37.0 \\
\hline 13. Rio Grande & 1.9 & - & 6.5 & - & 2.4 & - & 20.3 & - & 5.6 & - \\
\hline 14. Upper Colorado & 2.7 & - & 5.8 & 0.21 & 2.2 & 1.8 & 11.4 & 4.9 & 4.5 & 2.9 \\
\hline 15. Lower Colorado & 2.5 & - & 8.9 & 1.4 & 3.8 & 3.1 & 22.5 & 22.5 & 12.5 & 8.1 \\
\hline 16. Great Basin & 0.96 & - & 0.96 & - & 0.35 & - & 0.96 & - & 0.27 & - \\
\hline 17. Pacific Northwest & 0.13 & 1.0 & 3.9 & 2.7 & 2.4 & 2.0 & 10.6 & 31.8 & 11.8 & 7.6 \\
\hline 18. California & 19.2 & 0.53 & 32.5 & 8.2 & 14.8 & 12.2 & 49.3 & 91.6 & 39.3 & 25.5 \\
\hline Total Contiguous U.S. & 252.9 & 6.3 & 555.7 & 196.5 & 273.0 & 225.0 & 845.0 & $1,639.8$ & 693.0 & 449.0 \\
\hline
\end{tabular}

2 ERDA-48, Scenario V (June 1975), U.S. Forecast Divided into water Resource Regions by Reference 3 ratios.

${ }^{3}$ Espey, Huston \& Associates, Table 4.6, Utility Water Act Group report Section IX, from FPC Form 67 (1973).

SOURCE: Ref. 1 .

condenser reject heat will soon be installed at the Northern States Power Co., Sherburne County, coal fired stations. The Muscle Shoals, Alabama branch of the Tennessee Valley Authority (TVA) has been studing beneficial uses of waste heat since 1971. Waste heat applications studied there include: environmental control for greenhouses, raceway catfish production, environmental control for livestock housing, biological recycling of nutrients from livestock waste, and subsurface soil heating and irrigation. 
The amount of waste heat available is significant. TVA estimates that by 1990 it will produce over 12 trillion Btu's of waste heat. The waste heat from just the TVA Browns Ferry Nuclear Plant is sufficient to provide environmental control for approximately 1500 acres of greenhouses. (4) 


\section{COOLING ALTERNATIVES}

There are five principal options available to provide cooling for thermal power plants: once-through cooling, cooling ponds and lakes, closed cycle evaporative cooling towers, wet/dry cooling towers, and dry cooling towers. The 1970 relative mix of each type of cooling is shown in Table 2 .

TABLE 2. 1970 Mix in Percent (by Capacity) of Cooling System Type

\begin{tabular}{|c|c|c|c|c|}
\hline Water Resource Region & $\begin{array}{c}\text { Once-Thru } \\
\text { Saline } \\
\end{array}$ & $\begin{array}{l}\text { Once-Thru } \\
\text { Fresh } \\
\end{array}$ & $\begin{array}{l}\text { Cooling } \\
\text { Pond } \\
\end{array}$ & $\begin{array}{l}\text { Cooling } \\
\text { Tower }\end{array}$ \\
\hline 1. New England & 71.51 & 28.49 & $-\cdots$ & --- \\
\hline 2. Middle Atlantic & 61.09 & 38.91 & --- & --- \\
\hline 3. South Atlantic - Gulf & 37.38 & 55.33 & 4.57 & 2.72 \\
\hline 4. Great Lakes & --- & 99.70 & 0.16 & 0.14 \\
\hline 5. Ohio & --- & 83.57 & $r+$ & 16.43 \\
\hline 6. Tennessee & -- & 90.73 & 2.19 & 7.08 \\
\hline 7. Upper Mississippi & 12.44 & 85.08 & 13.46 & 1.46 \\
\hline 8. Lower Mississippi & -- & 68.53 & --- & 19.03 \\
\hline 9. Souris - Red - Rainy & -- & 100.00 & -- & -- \\
\hline 10. Missouri Basin & --- & 58.12 & 19.44 & 22.44 \\
\hline 11. Arkansas - White - Red & --- & 13.20 & 21.77 & 65.03 \\
\hline 12. Texas - Gulf & 27.30 & 15.30 & 36.00 & 21.40 \\
\hline 13. Rio Grande & --- & --- & --- & 100.00 \\
\hline 14. Upper Colorado & -- & -- & 86.58 & 13.42 \\
\hline 15. Lower Colorado & --- & -- & 4.87 & 95.13 \\
\hline 16. Great Basin & --- & 10.17 & 13.32 & 76.51 \\
\hline 17. Pacific Northwest & 5.14 & 94.86 & --- & --- \\
\hline 18. California & 78.27 & 6.48 & $\cdots$ & 15.25 \\
\hline
\end{tabular}

SOURCE: Ref. 5 .

Dry and wet/dry cooling are essentially zero percent. The relative water consumption of each cooling mechanism is shown in Table 3 . The values in Table 3 are approximately consistent for a single site, but differ among 
TABLE 3. Typical Water Consumption Data for Alternative Cooling Modes

\begin{tabular}{|c|c|c|}
\hline \multirow[b]{2}{*}{ Cooling Mode } & \multicolumn{2}{|c|}{$\begin{array}{l}\text { Approximate Annual } \\
\text { Gallons/Hour Per Gross kWe }\end{array}$} \\
\hline & Fossil" & Nuclear (LWR) $\uparrow$ \\
\hline Once-through . & $\ldots 0.30$ & 0.45 \\
\hline 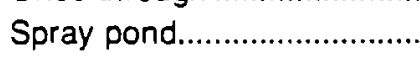 & $\ldots 0.40$ & 0.60 \\
\hline 1 acre per MW pond.............. & $\ldots 0.50$ & 0.75 \\
\hline 2 acres per MW pond........... & $\ldots 0.68$ & 1.0 \\
\hline Mechanical draft wet tower.. & $\ldots 0.43$ & 0.65 \\
\hline Natural draft wet tower ........ & $\ldots 0.38$ & 0.57 \\
\hline Dry tower (in-plant) ................ & $\ldots .022 \ddagger$ & 0.015 \\
\hline Peak shaved dry/wet systen & $\ldots .02-0.05$ & $0.02-0.07$ \\
\hline
\end{tabular}

"Fossil - 40\% gross efficiency with $15 \%$ heat loss up the stack †Nuclear - $33 \%$ gross efficiency

$\ddagger$ Includes ash sluicing

SOURCE: Ref. 1.

sites. The water consumption shown in Table 3 plus blowdown liquid discharge is the total water withdrawal requirement for a plant. The approximate relative cost of alternative cooling systems is shown in Table 4. These values are from a 1969 report and represent costs for a 1000 MWe nuclear plant.

A year ago, the use of once-through cooling and cooling lakes was severely limited by regulations of the U.S. Environmental Protection Agency (EPA). These regulations were set aside in a court case in July 1976. It is possible that limited use of these cooling modes may be acceptable in the future.

\section{ONCE-THROUGH COOLING}

Historically, once-through cooling without cooling towers has been the most common form of thermal power plant cooling, principally because of its low cost. This form of cooling was criticized for the ecological impact of the waste heat discharge. The Federal Water Pollution Control Act Amendments of 1972 (FWPCA) declared a national goal of el iminating the discharge of pollutants into navigable waters by $1985 .(7)$ Heat is included within the definition of pollutants. ${ }^{(8)}$ The Act also provides ${ }^{(9)}$ though, 
TABLE 4. Relative Costs of Alternative Cooling Systems for Nuclear Plant with $\Delta T=20^{\circ} \mathrm{F}$ (1969 Costs)

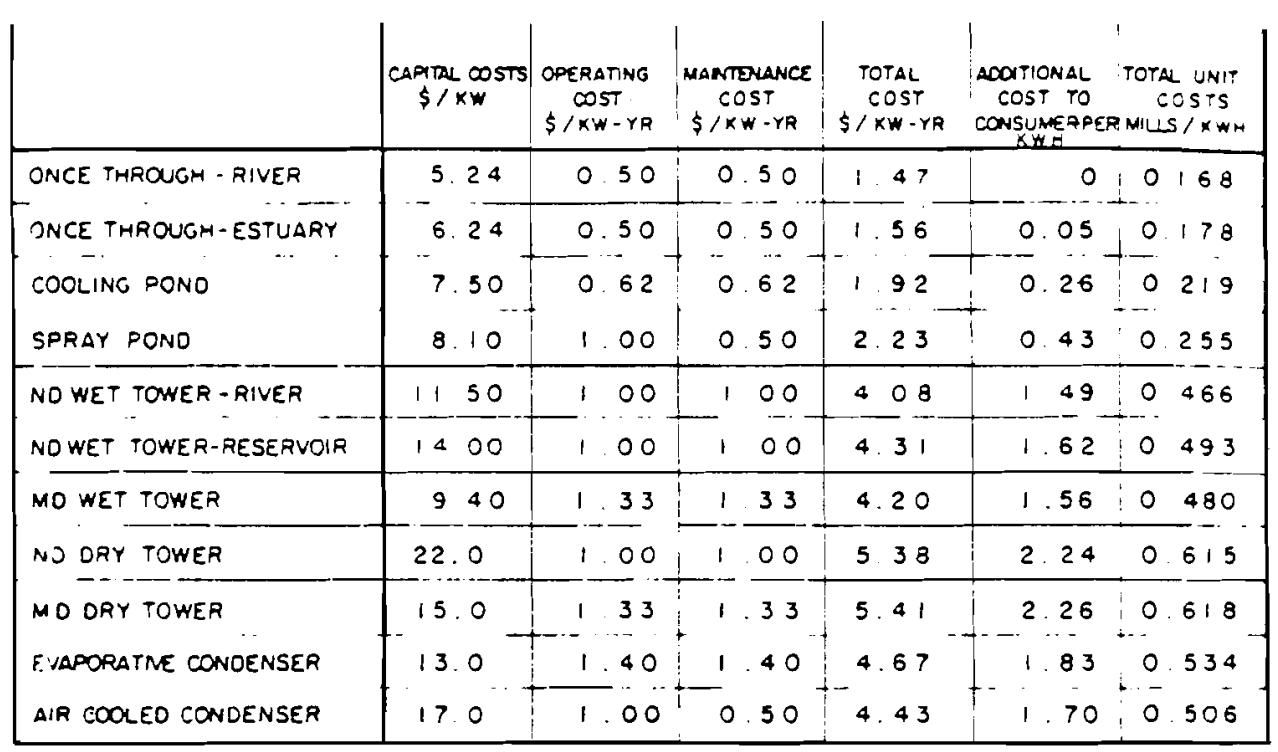

ND = Natural Draft

MD = Mechanical Draft

SOURCE: Ref. 4., p. 152.

that the Environmental Protection Agency (EPA) Administrator can accept some thermal discharge if the protection and propagation of a balanced indigenous population of shellfish, fish, and wildlife in and on the receiving body of water is assured. EPA responded to FWPCA by promulgating regulations which provided that subject to limited exceptions:

1. All existing generating plants of 500 MWe or more which came on line after January 1, 1970, and all existing units regardless of size which begin operation after January 1, 1974, must backfit closed-cycle cooling systems by Ju1y 1, 1981, (10) and

2. Discharge of heat from new steam electric power plants is permitted only in blowdown from recirculated cooling water systems and in blowdown from cooling ponds. (11) 
Thus, new generating unit could not use cooling lakes. Cooling ponds are not restricted. (Cooling ponds and lakes are distinguished on page 8.)

Both of these requirements were set aside in Appalachian Power $v$. Train (12) in a suit brought by 70 utilities composing UWAG. Revised regulations have not been published. The status of once-through cooling for both existing and future plants is thus uncertain. In practice, the trend to closed-cycle cooling is unlikely to be reversed and once-through cooling may not be accepted on future plants. If it is accepted in some areas, however, significant cost and water savings can be achieved.

The backfit requirements were set aside because the court found that EPA did not state the expected environmental benefits of reducing themal pollution. The court left open the possibility that the regulations might be found acceptable if EPA can fully explicate the reasons for the regulations. In particular, the court requested that EPA state the incremental benefits (not necessarily in monetary terms) to be expected from incremental reductions in thermal discharges.

The second requirement, that new plants discharge heat only in blowdown from closed cycle cooling systems and cooling ponds, was also set aside. The principal reasons stated for the court's decision was EPA's failure to consider the impact of regulations on water consumption in water-short areas. The court's decision to set aside these regulations raises the possibility that even once-through cooling may be accepted in 1 imited areas for new thermal power plants.

Appalachian Power decided two other significant issues. First it directed EPA to adopt a meaningful variance clause which would exempt power plants from the thermal backfit requirement in certain circumstances. The decision also directed EPA to consider a request made by the Atomic Energy Commission (AEC) (now the Nuclear Regulatory Commission (NRC)) that 55 nuclear power plants that have completed environmental impact statements be exempt from backfit requirements. 
One provision in the FWPCA which affects thermal power plant cooling merits mention. Section 306(c) of the Act permits states to apply and enforce standards stricter than EPA regulations if prior EPA approval for the state's permit system is obtained.

\section{COOLING PONDS AND LAKES}

The use of cooling lakes for future thermal power plants is also in doubt at the present time. EPA regulations distinguish cooling lakes from cooling ponds in the following manner: (13) cooling lakes are any manmade water impoundments which impede the flow of a navigable stream; cooling ponds are manmade impoundments which do not impede the flow of navigable streams. Navigable streams are broadly defined to include nearly all natural lakes, rivers, and streams. As noted above, before Appalachian Power $v$. Train, EPA regulations would have permitted new thermal power plants to discharge heat only in blowdown from cooling towers and cooling ponds. (11) Existing plants would continue to use cooling lakes, but new plants could not. (14) These regulations were set aside in the Appalachian Power case and EPA was directed to consider the impact of any revised regulations on the consumption of water. The court implied that geographically uniform regulations may not be acceptable because the value of water varies by location.

Prior to the Appalachian Power decision, EPA had published proposed regulations (15) which if adopted would relieve the restriction on the use of cooling lakes for new thermal power plants somewhat. The regulations have not yet been made final. The proposed regulations would allow the discharge of heat to new on-stream cooling lakes if the lake qualified as a recirculating cooling water body. To qualify, the lake would have to:

1. be environmentally acceptable,

2. discharge on a long-term average annual basis no more than $2 \%$ of the waste condenser heat,

3. discharge on a long-tem average annual basis no more than 100 cfs per 1000 MW generation capacity. 
As Table 3 indicates, cooling ponds consume approximately the same amount of water as wet towers. The principal advantage of ponds are their relatively low cost. The principal disadvantage is the large amount of 1 and required, on the order of 1.5 acre/MWe.

\section{EVAPORATIVE COOLING TOWERS}

Evaporative cooling towers have become the most common cooling mechanism for recent thermal power plants. Environmental pressures exerted by the AEC (now NRC) and EPA, which have acted under the authority and mandate of the FWPCA and the National Environmental Policy Act, have contributed most to the widespread use of wet evaporative cooling towers. Particular advantages of evaporative cooling towers include less heat discharge to the receiving water body and less total water withdrawal than once-through cooling. Additionally the large land areas required for cooling ponds and lakes is not needed. Disadvantages include the formation of fog from the warm, moist effluent and icing of structures near the towers in winter.

\section{DRY AND WET/DRY COOLING}

Although dry and wet/dry cooling have been common in Europe in small thermal plants for some time, they have only recently been introduced in the United States. Their principal advantage is low water consumption. Thus they can provide flexibility in power plant siting. In the case of a coal fired plant, a utility can make an economic trade-off of the cost of transporting coal to a site which would permit wet cooling versus the cost of building a mine-mouth plant using wet/dry or dry cooling and transmitting the power. The flexibility advantage is not as important with nuclear plants because the cost of transporting nuclear fuel cycle materials is relatively low, and plant sites can be selected to take advantage of available cooling water. A utility can also compare the cost of locating a dry or wet/dry cooled power plant near a load center to a wet cooled plant farther away from the load center. 
Another reason for choosing dry or wet/dry cooling would be to locate a new plant at an existing power plant site which is water constrained. Such location may speed up the licensing process, although this will not always be true (e.g., collocation at the St. Lucie nuclear facilities in Florida has not speeded up the licensing process). A more likely benefit of collocation of power plants is to take advantage of existing transmission corridors, avoid creating a new boom town and at the same time enhance the economic basis of the town created (or enlarged) by construction of the first plant. Certain economies-of-scale may also be possible, e.g., reduced exclusion area.

Secondary advantages of dry and wet/dry cooling in relation to all wet cooling are reduced fogging and icing, reduced blowdown disposal, and in the case of coal plants, reduced sulfuric acid problems.

The first large dry-cooled plant in the U.S. is the Wyodak facility under construction near Gillette, Wyoming. The plant is a 330 MWe minemouth coal-fired plant jointly owned by Black Hills Power and Light Company and Pacific Power and Light Company. Completion is scheduled for the summer of 1978.

The first large wet/dry cooled plant in the U.S. is San Juan III under construction northwest of Farmington, New Mexico. Completion is scheduled for summer 1979. The 466 MWe plant, a mine-mouth coal-fired facility, is owned by Public Service Company of New Mexico and Tucson Gas and Electric Company. San Juan IV, also a 466 MWe unit, will also utilize wet/dry cooling unless additional water becomes available to the utilities. Wet/dry cooling was chosen for San Juan III and IV because the utilities wanted to take advantage of an existing, dedicated site and the close proximity of the coal, but were unable to obtain sufficient additional water to utilize evaporative cooling. San Juan I and II, located at the same site, use wet cooling. 


\section{ECONOMICS OF COOLING TOWER ALTERNATIVES}

Two crucial elements in estimating the future demand for dry and wet/ dry cooling are their cost relative to other cooling options and the physical availability of water. Cost estimates are discussed in this chapter and water availability is discussed in Chapter IV.

\section{RELATIVE COST OF ALTERNATIVES}

Several recent studies have compared the cost of dry and wet/dry cooling relative to other cooling mechanisms. Based on present relative costs, two principal conclusions emerge. First, without a legal mandate for $i$ ts use, dry cooling is so expensive relative to other cooling possibilities that it will only be sparingly used in certain isolated areas such as the Wyodak facility near Gillette. The utilities at Wyodak had virtually no cooling water available and determined that use of dry cooling would be economically preferable to transporting the coal to a site with sufficient water to utilize evaporative cooling. Second, wet/dry cooling is significantly less expensive than dry cooling, but also considerably more expensive than total wet cooling. It is likely to be used more extensively than dry cooling, but for the most part it too will be utilized most often for mine-mouth plants or to permit siting at an existing power plant site.

A summary of the economic evaluations made in a recent study ${ }^{(1)}$ conducted by the General Electric Company is shown in Table 5. The costs are for cooling a light water nuclear reactor (LWR) and are in 1975 dollars.

\section{TABLE 5. Water Breakeven Costs $(\$ / 1000$ gal)}

Plant Location Lubbock, TX Raleigh, NC. Reno, NV

$$
\text { Wet Cooling Tower/50-50 Peak }
$$
Shaved Dry-Wet Cooling System

$\$ 2.00$

1.60

1.70
50-50 Peak Shaved Dry-Wet Cooling System/Dry Cooling Tower

$\$ 18.00$

32.00

53.00

SOURCE: Reference 1. 
Table 5 is interpreted in the following manner: for a LWR in Lubbock, Texas, a 100\% wet cooling tower would be chosen if water costs are below $\$ 2.00 / 1000$ gal. Between $\$ 2.00$ and $\$ 18.00 / 1000$ ga 1. a 50-50 Peak Shaved Wet-Dry Cooling Tower System would be the economic choice. When the cost of water exceeds $\$ 18.00 / 1000$ gal., dry cooling is the economic choice.

Another recent study ${ }^{(16)}$ conducted by United Engineers and Constructors estimated that water would have to cost $\$ 4.50 / 1000 \mathrm{gal}$. (in 1985 dollars or about $\$ 2.50$ in 1975 dollars, assuming $6 \%$ escalation) before wet/dry cooling would be the economic choice over totally wet tower cooling. The calculations in this case were made for a 1000 MWe LWR using meteorological data for Boston.

A third study conducted at the Iowa Institute of Hydraulic Research (17) reached similar conclusions. They concluded the wet/dry cooling becomes competitive with wet cooling at water costs on the order of $\$ 2.00 / 1000 \mathrm{gal}$.

The water breakeven cost estimates in these studies are clearly subject to many assumptions and the reader is referred to the source documents for additional information. All three studies do use the fixed source-fixed demand cost system, whereby each cooling system is compared assuming a fixed electricity demand. Dry cooling reduces the thermodynamic efficiency of a power plant during warm weather. The three studies assume that replacement power necessitated by the reduced generating capacity is purchased from fossil-fueled gas turbine peaking units. This penalty cost is added to the cost of dry cooling and to wet/dry systems when operating in the dry mode. Critics of this approach argue that utilities would not really operate in this manner. Instead of purchasing peaking power, they would simply bring on their next power plant somewhat sooner. The appropriate penalty, they argue, is not the cost of peaking power, but the cost of bringing on-1 ine the utilities' next power plant somewhat sooner. Alternatively, an appropriate penalty would be the incremental cost of building a larger capacity dry or wet/dry cooled plant. Clearly the magnitude of the penalty using either of these alternatives will be site dependent. Additional study to compare the magnitude of the penalties using all three approaches appears to be warranted. 
WATER COSTS

The cost of water in most of the U.S. is well below the $\$ 1.60-2.50 / 1000$ ga1. breakeven point cited in the previous section. The cost of cleaning up agricultural and municipal waste water is also generally less than the breakeven point. Finally, in most cases, it will be possible to purchase farms outright and obtain water rights for substantially less than $\$ 1.60 /$ $1000 \mathrm{gal}$. of water. These costs suggest that where water is available, it can be treated and delivered to the plant site at less than $\$ 1.60 / 1000$ gal. and the economic choice will be to use evaporative cooling.

\section{Water Purchase}

The cost of purchasing fresh water ranges from virtually zero to as much as $\$ 0.60 / 1000$ gal. for municipal water in California. (1) In most cases someone exercising a riparian or appropriate water right merely has to pay for the improvements necessary to divert the water. The cost of the water is zero. The Bureau of Reclamation simply requires farmers to repay its cost of delivery. Usually the cost to the farmers is well under $\$ 20 /$ acre-ft $(\$ 0.06 / 1000$ gal.). On the Columbia Basin Project in Washington State, for example, it ranges from $\$ 3.00-\$ 6.00 /$ acre-ft. Private irrigation districts generally also charge their delivery costs. One source reported in 1972 that water rights in a mutual water company in Utah had traded between $\$ 2.00$ and $\$ 20.00 /$ acre-ft $(\$ 0.01-\$ 0.06 / 1000$ ga1.). The cost of the water varies with the age of the irrigation district and the extent to which the diversion improvements have been paid off. Dr. Alfred Marsh, Extension Irrigation and Soils Specialist at the University of California at Riverside, indicated to the author that farmers in the Imperial Valley Irrigation District in Southern California pay as little as $\$ 5 /$ acre-ft because the district is long established. He also indicated that farmers 100 miles away in southern San Diego County currently pay up to $\$ 150 /$ acre-ft $(\$ 0.46 / 1000$ gal.), probably the highest irrigation cost in the country. The high cost results in part because the district is relatively new and because there are high energy costs to deliver the water. 
Water delivery costs for energy projects in North Dakota, Wyoming, and Montana were estimated in the Northern Great Plains Resources Program report. (19) Average annualized delivery costs (1973 dollars) ranged from $\$ 38 /$ acre-ft $(\$ 0.12 / 1000$ gal.) for North Dakota under a low energy growth assumption to $\$ 147 /$ acre-ft $(\$ 0.45 / 1000 \mathrm{gal}$.$) for Montana and Wyoming under$ medium and high energy growth asssumption. The same study indicated that where ground water is available in Montana and Wyoming it could be delivered at an annualized cost of about $\$ 50 /$ acre-ft.

Municipal Waste Water

The use of municipal waste water for power plant cooling is an increasingly attractive option. A principal advantage is that it provides an assured source of supply. Southwestern Public Service Company has been using municipal waste water to cool plants near Amarillo, Texas for 15 years and plants near Lubbock, Texas for four years. (20)

Six southwestern utilities building three pressurized water nuclear reactors of approximately 1270 MWe each will use municipal sewage water for cooling. The reactors, designated the Palo Verde Nuclear Generating Station, will be located about 36 miles west of Phoenix. The sewage water to be used will have secondary treatment. The utilities will further treat the water before using it for cooling. The final environmental impact statement for the plants $(21)$ indicates that use of wet/dry cooling rather than wet cooling would add $\$ 39,109,000$ to the total annualized cost of the three plants and reduce average water consumption by $16,050 \mathrm{gpm}$. This suggests that water would have to cost $\$ 4.63 / 1000 \mathrm{gal}$. ( $\$ 1509 / \mathrm{acre}-\mathrm{ft}$ ) before wet/dry cooling would be the economic choice. These costs must be used with caution because the statement does not indicate what year dollars are utilized for the computations.

Municipal waste water was considered for use at the Rancho Seco Nuclear Unit No. 2, about 25 miles east of Sacramento, California. The cost of conveying and treating the water was estimated to be $\$ 358 /$ acre-ft $(\$ 1.10$ ) 1000 gal.). (22) The alternative was rejected in this case because much less expensive (\$16/acre-ft) water was available from the Folsom Canal. 
Agricultural Waste Water

The cost of treating highly saline agricultural waste water for power plant cooling begins to approach the breakeven water costs in the $G$. E. study ${ }^{(1)}$ but is still appreciably less. Recall that the G. E. authors estimated the breakeven point for choosing wet/dry cooling over wet cooling to be $\$ 1.70$ (1975 dollars) for Reno, Nevada, and $\$ 2.00$ for Lubbock, Texas. A recent study conducted by Kaiser Engineers ${ }^{(23)}$ estimates the cost of treating highly saline ${ }^{-}$/ agricultural waste water in the San Joaquin Valley of California for use as makeup water in a 1000 MWe power plant. The most expensive option considered involved water treatment and a disposal system using a brine concentrator or crystalizer and small evaporation ponds. The cost for this system (converted to 1975 dollars) is about $\$ 1.15 / 1000$ gal. A system using large evaporation ponds with no prior brine concentration would cost about $30 \%$ less.

Irrigated Farm Purchase

Finally, it is worthwhile to consider what it would cost a utility to obtain water rights by purchasing irrigated farm(s) outright. It appears that water could also be obtained in this way at less than the breakeven cost for selecting wet/dry cooling. Examination of the Farms and Ranches classified sections of the Friday editions of the Wall Street Journal reveals that irrigated western farms have asking prices in the range of $\$ 1000-\$ 4000 / a c r e$. Typically, farmers have rights to apply 3-6 ft of water per acre per year. A utility purchasing a farm would only obtain the consumptive water rights of the particular farmer. Water not consumed in growing the particular crop either percolates into the ground water or is carried away as surface runoff and in many cases is reapplied to downstream land. Mr. Mel Hagood, Irrigation Specialist for the Washington State Extension Service in Prosser, Washington, indicated to the author that in the Columbia Basin Project of Washington State, irrigation efficiencies (i.e., water consumed/water withdrawn $\times 100 \%$ ) are about $43 \%$ for

a Average concentrations: $\mathrm{Na} 873 \mathrm{ppm}, \mathrm{Ca} 257 \mathrm{ppm}, \mathrm{Ci} 359 \mathrm{ppm}, \mathrm{SO}_{4} 2314 \mathrm{ppm}$, total dissolved solids $4319 \mathrm{ppm}$. 
surface application and $64 \%$ for sprinkler irrigation. Efficiences elsewhere in the country vary with water cost, the climate, soil, and type of irrigation equipment. In areas where water costs are very high (e.g., San Diego County), drip irrigation is frequently used and irrigation efficiency can be as high as 90\%. Table 6 presents the cost of water acquired by farm purchase under representative assumptions. The final column is the annualized cost assuming a 30-yr plant 1 ife and a 10\% capitalization rate. The calculations indicate that the annualized cost is likely to range from $\$ 0.25-\$ 0.50 / 1000$ gal. of water. This cost could possibly be reduced somewhat if the farm residence and/or farm and irrigation equipment can be salvaged, or if resale of the land for dry land farming is feasible.

TABLE 6. Cost of Water Acquired by Purchasing Irrigated Farms

\begin{tabular}{|c|c|c|c|c|c|}
\hline & Land Cost & Feet of Hater & Irrigation & \multicolumn{2}{|c|}{ Capitalized Cost } \\
\hline & & & ETTICTency & acre-ft & $\$ / 1000 \mathrm{ga}$ \\
\hline$A$ & 2000 & 4 & $60 \%$ & $\$ 88$ & $\$ 0.27$ \\
\hline 8 & 4000 & 4 & $70 \%$ & $\$ 151$ & $\$ 0.46$ \\
\hline C & 1500 & 3 & $40 \%$ & $\$ 132$ & $\$ 0.41$ \\
\hline$D$ & 3000 & 4 & $50 \%$ & $\$ 159$ & $\$ 0.49$ \\
\hline
\end{tabular}

Beyond the purchase cost, the utility would have to pay the annual assessment, which as noted earlier is usually less than $\$ 0.10 / 1000$ gal., but could range as high as $\$ 0.40 / 1000$ gal. Additional costs could be required for water treatment and diversion equipment. A utility may also have to build a water storage basin if $i$ ts water rights are sufficiently unreliable that it could run out of water in low water years, such as the Western states are currently experiencing. Occasionally a water storage facility may also be required to consume water during months when the land was not previously irrigated. Construction of a storage basin for the latter reason only may not be needed if water supply is not a problem in winter months and water is available for consumption, if adequate storage on the stream already exists, ${ }^{(24)}$ or if storage in underground basins is possible. (25) 
That cost figures suggest utilities can purchase irrigated farms outright to put the water to an alternative use should not be too surprising. Prior studies have estimated the long-run value of water for irrigation in the west to be in the \$15-\$40/acre-ft range at the farmer's headgate. The average value of water for irrigation in Maricopa County, Arizona, site of the Palo Verde nuclear generating station, was estimated to be less than $\$ 0.50 /$ acre-ft $(\$ 0.15 / 1000 \mathrm{ga} 1$.$) , with a maximum value of \$ 370 /$ acre-ft $(\$ 1.13 / 1000$ ga 1.$) .(27)$ One walnut farmer operating in the Sacramento valley turned down a recent offer to provide water for $\$ 90 / a c r e-f t$, candidly stating that he couldn't afford to pay the price. ${ }^{(28)}$ The farmer, who had been hard hit by the western drought, usually pays $\$ 5 / a c r e-f t$. 


\section{CRITICAL WATER AVAILABILITY AREAS}

\section{WATER AVAILABILITY AND CONSUMPTION IN THE U.S.}

The analyses in Chapter III suggest that when water is physically available and can be acquired by purchase or otherwise, a utility would normally select wet cooling over wet/dry cooling towers. This chapter briefly addresses the question of availability of water. a/ The principal conclusion is that sufficient water is available to utilize wet evaporative cooling towers for projected thermal power plants in most sections of the country through the year 2000. Certain sections of the country, especially the Southwest, will experience physical shortages and can be expected to utilize some wet/dry cooling.

Absolute water scarcity is not likely to become a problem in the U.S. in the foreseeable future. The mean annual runoff in the continental U.S. is 1200 billion gal. per day (bgd). Current storage capacity provides about 280 bgd in dependable surface supply. An additional 70 bgd are withdrawn from underground water sources and 55 bgd from saline water supplies. (29) In spite of this water abundance, shortages do occur and will continue to occur because the water is not uniformly spread throughout the country. Interbasin water transfers are often prohibitively expensive, especially if they involve long distances.

By far the greatest use of water in this country is for agriculture. The U.S. Geological Survey ${ }^{(30)}$ estimated that 88 bgd were consumed in the U.S. and Puerto Rico in 1970. This includes water from fresh, saline,

a/ Detailed estimates of water availability are available from several sources. The most recent data is that collected by the U.S. Water Resources Council (WRC) for its 1975 Water Assessment Study. This study is scheduled to be completed in December 1977. Published data based on the 1968 National Water Assessment is in an earlier WRC study, Water for Energy Self-Sufficiency, October 1974 and the report upon which it is largely based, Arthur D. Little, Inc., Project Independence Blueprint: Water for Energy, submitted to the Federal Energy Administration, September 1974. 
ground, and waste water sources. Of this amount, 73 bgd (83\%) was used for irrigation, 5.9 bgd $(7 \%)$ for public supplies, 3.4 bgd (4\%) for rural use, 1.04 bgd (1\%) for steam electric use ( 820 bgd of which was saline water), 5.3 bgd (6\%) for self-supplied industrial use, and the remainder for miscellaneous purposes.

Using data in Tables 1 and 3 , cooling water consumptive requirements in the year 2000 can be calculated. A high estimate can be made by assuming that all cooling is done by mechanical draft wet cooling towers. Using this assumption, the total consumptive water requirement under the ERDA projection is $14.15 \mathrm{bgd}$; the UWAG projection requires $34.30 \mathrm{bgd}$.

The greatest competition for fresh water is likely to occur in the 11 westernmost states of the continental U.S. These are the states where rainfall is the lowest and irrigation is most intensive. The Westwide Study, (31) citing projections made by the Western Systems Coordinating Council, estimated that $2.5 \mathrm{M}$ acre-ft annually of fresh and waste water potentially would be consumed to meet cooling requirements in the 11 states by the year 2000. To put this figure in perspective, the estimated water consumption (including ground water) for irrigation in 1970 in these 11 states was 59.6 M acre-ft. (32)

REVIEW OF STUDIES ESTIMATING THE DEMAND FOR WET/DRY COOLING

Two recent studies have considered the physical supply of water by region throughout the United States and then estimated the demand for wet/dry cooling through the year 2000.

The first study, prepared by the General Electric Company, (1) projected that the geographic areas facing the most critical water shortages for thermal power plant cooling would be the Texas Gulf region, California, and the upper and lower Colorado River Basins. It projected that in the Texas Gulf and California regions, sufficient water for wet cooling could be found from waste, ocean, or ground water and that wet/dry cooling could thereby be avoided. In the Colorado River Basin it projected that thermal power plants coming on line between 1985 and 2000 would potentially require 
wet/dry cooling. Using data in Table 1, this means that 6 to 23 GWe of nuclear power and 5 to 19 GWe of fossil fired power plants could require wet/dry cooling through the year 2000, depending on the rate of power growth. The total projected need is thus 11 to 42 GWe. In making this projection the G.E. authors assumed no water transfer from irrigation to power plant cooling. If such transfer occurs, which seems likely to this author, the demand for wet/dry cooling would be at the lower end of the ranges regardless of the rate of electricity consumption growth.

The second study, ${ }^{(33)}$ prepared by the Hanford Engineering Development Laboratory (HEDL) utilizes a finer geographic breakdown than the first. The study examines 217 river basins or water resource subregions in the U.S. Water availability and consumption data is provided for each region. Other than a few isolated plants, such as Wyodak and San Juan, no wet/dry or dry cooling was projected to be needed until 1990. For the period 1990-2000, the following projections for wet/dry or dry cooling (for both fossil and nuclear facilities) are made:

$\begin{array}{lr}\text { California } & 14 \text { to } 22 \text { GWE } \\ \text { Denver Area } & 2 \text { to } 5 \text { GWe } \\ \text { Southern Great Plains } & 4 \text { to } 11 \text { GWe } \\ \text { Upper Colorado River Basin } & 1 \text { to } 2 \text { GWe } \\ \text { Lower Colorado River Basin } & 2 \text { to } 4 \text { GWe } \\ \text { Great Basin } & 1 \text { GWe } \\ \text { TOTAL } & 22 \text { to } 44 \text { GWe }\end{array}$

In addition to these areas, the HEDL study identified the middle Atlantic Coast states as areas where salt water cooling would be necessary. If these states elect not to make coastal sites available for power plants, wet/dry cooling for inland plants would be needed before the year 2000 . This projection is comparable on the high end to that made in the $G$. $E$. study. It is considerably higher on the low end. A major difference between the two estimates is that the HEOL study assumed that only $3 / 4$ of the projected wet cooling requirements in California between 1990 and 2000 could be obtained from waste water and/or transfer of water from 
irrigation. The G.E. study assumed that ocean cooling, waste water, new water allocations, and water transfers could probably be made sufficiently available to provide for wet cooling.

Based primarily on political considerations discussed in Chapter $V$, this author believes that some wet/dry cooling in California will be required. This added demand for wet/dry cooling should be more than offset by transfers of water from agricultural to industrial use and the possibility of future use of once-through cooling and cooling ponds and lakes. Applying these considerations to the G.E. and HEDL estimates, it seems reasonable to this author to expect that approximately 20 GWe of wet/dry cooling will be required primarily in the southwest by the year 2000 .

\section{REGIONAL PROJECTIONS OF WATER AVAILABILITY FOR COOLING}

A number of regional studies have been prepared regarding the availability of water for general energy development. Some of them are reviewed in this section.

\section{Colorado River Basin}

The Colorado River system is subject to two important allocation laws. The 1922 Colorado River Compact assures Arizona, California, and Nevada a combined allocation of at least $75 \mathrm{M}$ acre-ft of water in each successive 10-year period. The Mexican Water Treaty of 1944 assures Mexico an annual amount of $1.5 \mathrm{M}$ acre-ft, except in times of extreme shortage. Water supply and use statistics for the entire Colorado River have been publicished by Kneese and Brown; (29) Table 7 contains data taken from their Table 1. The data include ground water use.

TABLE 7. Water Supply and Use in the Colorado River System (Thousands of Acre Feet per Year)

\begin{tabular}{|c|c|c|c|c|}
\hline \multirow[b]{2}{*}{ Year } & \multirow[b]{2}{*}{ Water Supply } & \multicolumn{3}{|c|}{ Water Use } \\
\hline & & Agriculture & Steam-Electric & Other \\
\hline 1960 & 12,746 & 14,536 & 14 & 127 \\
\hline 1980 & 12,746 & 13,076 & 46 & 446 \\
\hline 2000 & 12,746 & 12,484 & 112 & 780 \\
\hline
\end{tabular}


It is apparent from Table 7 that agricultural water consumption will continue to dwarf consumption for energy. Both the G.E. and HEDL studies projected a need for wet/dry cooling in the Colorado River Basin. On an overall basis for the western states, it appears that the key element in determining the extent of the need will be the extent to which agricultural water rights can be obtained and transferred in sufficient quantity and in appropriate locations to permit completely wet cooling. Of course, a utility could still decide that site specific locational factors suggest wet/dry cooling for other reasons. Further discussion regarding obtaining agricultural water rights is in Chapter $V$.

\section{Upper Colorado River Basin}

The Department of the Interior released a report ${ }^{(35)}$ in 1974 which projected water use from the Colorado River for Colorado, New Mexico, Utah, and Wyoming. Figure 1 is reproduced from this report. The study assumes that $5.8 \mathrm{M}$ acre-ft should be available to the four states on a continuing basis. Other assumptions inherent in Figure 1 are: (1) no wet/dry or dry cooling, (2) no weather modification, (3) some ground water withdrawal, and (4) minimal transfer of water from agricultural use to other uses. With these assumptions water use reaches $5.8 \mathrm{M}$ acre-ft about 1991. If water for agriculture is made available for energy, this date can be extended further into the future. Transfer seems likely because of the economic reasons discussed in the preceeding chapter and because the four states have no significant restrictions on the transfer of water rights (see Chapter V).

\section{Upper Missouri River Basin}

The Upper Missouri River Basin has considerably more water available for energy development than the Colorado River system. The U.S. Department of the Interior reached the following conclusion.

"The total unallocated water supply in the Upper Missouri River Bas in appears to be ample, through the year 2000, to meet all projected needs including a high degree of energy development. However, in the Yellowstone subbasin there is a problem of distribution of supply from point of origin to point of potential need. "1(36) 
FIGURE 1. Upper Colorado River Basin Water for Energy 1974 to 2000

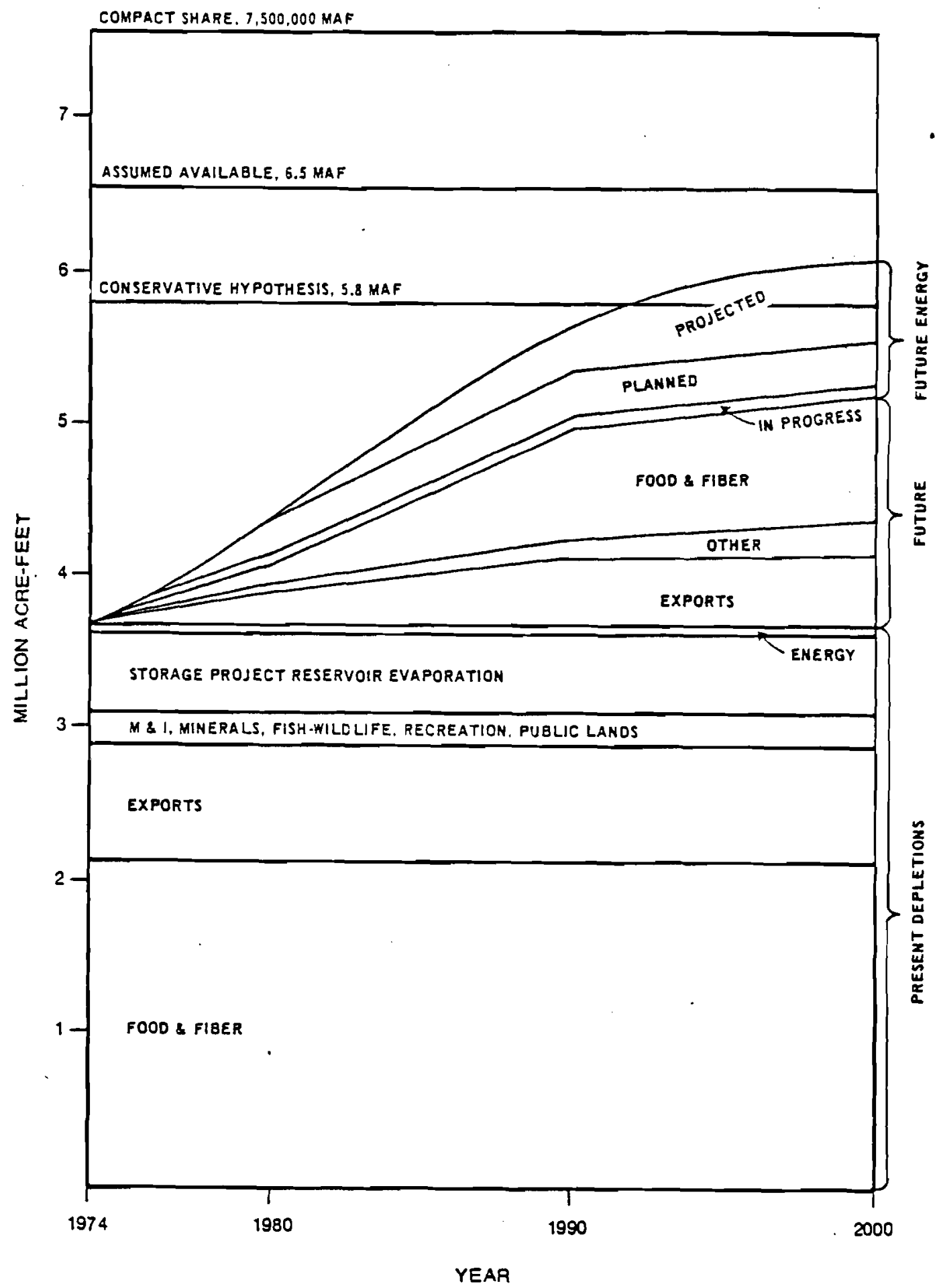

SOURCE: Ref. 35 . 
The Northern Great Plains Resource Program study (19) reaches a similar conclusion. The main stem of the Missouri River has an abundance of stored water, much of which is available for allocation. Although the Big Horn River is the only major stream in the Yellowstone Basin with significant storage capacity at the present time, the study concludes that there is sufficient storage in the Basin to supply the needs of coal development to the year 2000. This conclusion assumes evaporative cooling for all coal fired thermal power plants. A recent study prepared by the Montana Department of Natural Resources and Conservation ${ }^{(37)}$ basically agrees with this conclusion but adds as a caveat that "two of the tributaries (of the Yellowstone River), the Tongue and the Powder, are not, under current conditions, dependable sources for appropriation for additional continuous, year-round use or even for the full irrigation season." A moratorium on acquisition of new water rights of 20 cfs or greater from the Yellowstone River, which was initiated in 1974, is scheduled to expire January $1,1978$. $(38)$

The western Dakota tributaries of the Missouri River can provide only minimal amounts of water when compared to the main stem Yellowstone or Missouri Rivers. (39)

\section{California}

The water supply picture in California is complicated by two important factors. Power plant sites on the California coast have access to abundant ocean water for cooling. Location on the coast is difficult for a number of reasons though, particularly seismic, environmental and aesthetic concerns. Use of water for cooling inland power plants is complicated by the policy statement of the California State Water Resources Control Board. (40) Principle 1 of the Board's policy statement is that water for thermal power plant cooling should come from the following sources in order of priority: (1) waste water being discharged to the ocean, (2) ocean water, (3) brackish water from natural sources or irrigation return flow, (4) inland waste waters of low total dissolved solids, and (5) other inland waters. Principle 2 states that use of fresh inland waters for cooling will only be 
approved when it is demonstrated that other water sources would be "environmentally undesirable or economically unsound". These policies, plus the opposition of the California Farm Bureau Federation to transfer of water from agricultural use, suggest that some wet/dry cooling is inevitable in California over the next 20 years. The HEDL projection of wet/dry cooling in California may thus be more accurate than the G.E. projections.

Currently power plant cooling in California consumes 32,000 acre-ft/yr of water. (41)

The State estimates that if all proposed inland power plants utilize wet cooling, about 800,000 acre-ft/yr will be required by 1995 .

The State's present annual water demand is $37 \mathrm{M}$ acre-ft; irrigated agriculture takes $85 \%$ of the demand. Ground water provides $40 \%$ of the State's demand; however, the current overdraft is about $2.2 \mathrm{M}$ acre-ft/yr.

The Colorado Desert hydrologic area within California is identified by the state as having the greatest potential for pressure on water resources. Cooling water demand in this area could be 340,000 acre-ft/yr by 1995. This figure represents about $20 \%$ of current agricultural use. ${ }^{(43)}$ The Colorado Desert hydrologic area does, however, have considerable agricultural waste water that is potentially available for thermal power plant. About 400,000 acre-ft/yr of irrigation drainage water returns to the Colorado River from the Palo Verde Valley outfall drain. ${ }^{(44)}$ If final state approval is obtained, the San Diego Gas and Electric Company will eventually consume about 34,000 acre-ft/yr of this water to $c 001$ its two sundesert nuclear plants. a/ In addition to the Palo Verde waste water, about $1.3 \mathrm{M}$ acre-ft of primarily agricultural waste water enters the Salton Sea each year. Nearly $1.0 \mathrm{M}$ acre-ft of this total is irrigation waste water from the Imperial valley. (44)

a/ The preliminary report of the California Energy Resources Conservation and Development Commission, 76-NOI-2, issued April 14, 1977 requests the utility to submit in subsequent hearings a "comparative cost/benefit analysis" of wet/dry vs. wet cooling for the two units. 


\section{ALTERNATIVES FOR ACQUIRING INLAND WATER AND ASSOCIATED DIFFICULTIES}

Five alternatives for acquiring inland water rights are discussed in this chapter: exercise of appropriation and riparian rights, acquisition of water from Federal water projects, the purchase of water from private owners and water districts, and the pumping of ground water. Difficulties associated with each type of acquisition are discussed.

APPROPRIATION

Most of the states where water allocation problems are likely to occur follow the appropriation system of water rights. There are 18 appropriation states. They include North Dakota and Texas, and all states on the line between and west thereof except Hawaii. Certain states (e.g., Utah, Nevada, and Idaho) have rejected most riparian concepts (see section on riparian rights). Other states (e.g., Texas, California, and Washington) recognize certain riparian rights.

The essence of the appropriation system of water rights is stated in the following quotation from the Summary-Digest of State Water Laws prepared for the National Water Commission.

"The barest essence of the law of appropriation is that a water right is acquired by diverting water from a natural watercourse and applying it to a beneficial use. The water right carries a 'priority' date, which is the date that the first act was done to initiate the right, and the consequence of the priority date is that the water right will have a superior call upon the watercourse over all rights subsequently initiated. When a stream becomes 'over appropriated, so that the call upon the stream is in excess of the water in $i t$, then the owner of the oldest water right is first entitled to his full delivery of water, and then the next oldest right is fully satisfied, and so on down the line until the water supply is exhausted -and those with the most recently acquired rights get no water at a11." (45)

Application for new water rights are generally made to a central state office, often the State Engineer. Until recently the only criterion utilized by the engineer in processing new applications was whether unappropriated 
water was available. A number of additional public interest criteria have been added to the priority criterion by state legislatures in recent years. These include whether instream uses, fishery resources, water quality, vegetation, and aesthetic amenities will be protected. Alaska, ${ }^{(46)}$ California, (47) and Oregon ${ }^{(48)}$ have passed legislation providing for some form of public interest standard in issuing new water rights. In Nevada, the State Engineer is allowed to consider the state's public interest and economic welfare in reviewing applications to appropriate or change the use of water for generating electricity to be exported out of state. (49) South Dakota requires applications for the appropriation of over 10,000 acre-ft/yr to be submitted to the state legislature. ${ }^{(50)}$ The 1976 Utah legislature authorized the State Engineer to put a time limit on industrial water appropriations. At the expiration, the water would revert to the state.

Acquisition of new water rights in the West is not likely to be a significant source of cooling water in the future. This is because in many Western states, streams are fully appropriated and the paper water rights exceed the yield of the watercourses. Utah, Nevada, New Mexico, Arizona, and much of Colorado and Montana fall in this category. (51) In states where water is not fully appropriated, a utility may not be able to acquire rights of sufficient quantity and seniority to meet its cooling needs.

\section{EXERCISE OF RIPARIAN RIGHTS}

Riparian water rights arise by virtue of ownership of real property bordering natural water courses. ${ }^{(45)}$ The riparian water right is the right to make a reasonable use of the water. Reasonableness is not subject to precise definition, but depends on a variety of factors, including the nature of the use and the quantity of water in the watercourse. Traditional riparian water use is characterized by many uncertainties regarding the nature, extent, and scope of existing uses and the quantity of water available for new uses. Another element of uncertainty is what land the water can be used on. Traditionally water could be used only on riparian land, i.e., land adjacent to the waterway. This rule has been relaxed in some jurisdictions, but the criteria used to determine where water can be utilized are often 
inconsistent. These elements of uncertainty are particularly undesirable for a utility seeking water for cooling.

Because of the uncertainties associated with traditional riparian rights, many Eastern states have adopted water permit systems. The systems differ from state to state; however, permits are usually administered by a central state agency and are issued only if existing riparian and pemit uses are not adversely affected. (45) Thus an element of priority does usually exist in permit systems.

\section{ACQUISITION FROM FEDERAL WATER PROJECTS}

Acquisition of water from the large Federal water resource projects is perhaps the most likely source of cooling water. In the West, it is usually acquired from Bureau of Reclamation projects or the Corps of Engineers and in the East from Corps of Engineers projects. Prior Bureau policy was apparently to acquire a state water right for all water to be stored in the reservoir and then sell the water to water districts and others. (45) In recent years the states have been allowed to participate more actively in marketing the water from Bureau projects. Mr. William Crosby, a water marketing official with the Bureau of Reclamation in Billings, Montana indicated to the author that the Bureau now requires water applicants to obtain state approval before a water right is issued. In two recent instances the Bureau has allocated 300,000 acre-ft of water directly to Montana and South Dakota for allocation. The water is from storage reservoirs on the main stem of the Missouri River. The Corps apparently has always required water applicants to acquire their actual water rights under the state law. (45)

The principal general authority for the Bureau of Reclamation to sell water for industrial purposes is the Reclamation Project Act of 1939 (43 U. S.C. $\$ 4851(c)$ ) and the Water Supply Act of 1958 (43 U.S.C. \$3906). A Federal District Court in Montana ${ }^{(52)}$ cited this authority as one reason for allowing the Bureau to market water for industrial purposes out of the Yellowtail and Boysen Reservoirs, located in Montana and Wyoming. The 
plaintiff in the case argued that Congress had not authorized the construction of the reservoirs for the purpose of marketing water to industrial users.

As discussed elsewhere in this paper, there are significant economic incentives to transfer irrigation water to use for power plant cooling. The ability to transfer water authorized for irrigation by the Bureau of Reclamation is somewhat unclear. Since about $25 \%$ of the irrigated 1 and in the Western states is supplied with water from Bureau of Reclamation projects, transferability is an important issue. (53) In basins such as the Missouri, where significant unallocated water exists, transfer of Bureau water allocations will not be a problem in the near future. In other basins, such as the Colorado, it is already an important issue.

Frank Trelease, Professor of Law at the University of Wyoming, makes the following statements ${ }^{(53)}$ regarding the transfer of water allocated by the Bureau of Reclamation.

"In general, there is no express restriction in Federal
law against transfers, and although water rights are
made appurtenant to land and one landowner may not by
purchase or otherwise irrigate more than 160 acres,
these provisions do not seem to add up to a prohibition
of sales. Practically all Bureau of Reclamation repay-
ment contracts, however, require the consent of the
Bureau to any transfer of water rights. officials of
the Bureau have generally had a strong policy against
transfer of project water by owners of irrigated land.
Their reluctance is based in part on the theory of
preventing windfall profits that would accrue to the
farmer who reaps the irrigation subsidy in such case,
in part on the fear of jeopardizing repayment. Since
no firm policy has been established at the national
level, in most areas transfers are discouraged, but
in others, as in the Northern colorado Conservancy
District, there is an active market in project water."

In a study prepared for the National Water Commission in 1970, (54) Meyers and Posner found no opposition from top Bureau of Reclamation officials to the transfer of water from irrigation to industrial use. They speculated, however, that regional officials may resist such transfers. 
The final report of the National Water Commission recommends that transfers of water rights obtained through Federal agencies be permitted as long as payment of the transferor's financial obligation to the Federal agency is assured. (55)

\section{TRANSFER OF STATE WATER RIGHTS}

The acquisition of water that is currently being used for alternative uses is likely to be an important source of cooling water in the future. This will be especially true in the West where many streams are already fully appropriated.

Assembling water rights for a new use is a complicated process. The procedures to be followed are generally set out in statutes and case law, and differ from state to state. Many of the generic problems that exist are identified and discussed in an article by Richard Dewsnup. (18) His article is specifically addressed to water rights in Western states; however, many of the problems apply in Eastern states as well. Among the problem issues he identifies are the following:

(1) Existing water rights may be unrecorded.

(2) Recorded water rights may be incomplete and inaccurate. The amount of return flow associated with the water right is often not quantified. This is especially significant to a utility, because it affects the amount of water available for evaporative cooling consumption.

(3) The recorded "paper rights" often exceed the amount of water physicaliy needed by the water right holder.

(4) Some water rights appearing on the record as valid may be imperfected or lost as a result of abandonment, forfeiture, or prescription.

Particular issues important to water transfers under the appropriation and riparian systems and for water irrigation districts are discussed in the following subsections. 


\section{Appropriation System}

Generally, Western water rights are treated as salable property rights. (56) Rights are granted in perpetuity, but can be transferred to accommodate new uses. Transfer of water rights normally must be approved by the state water rights administrator. The transferor may only transfer the water rights he owns. The general, but not universal, rule is that transfers to new users and new uses is allowed as long as no other appropriator is injured thereby. Changes in diversion point are generally always allowed as long as other appropriators are not injured.

Water rights can be sold separately from the land on which the water is used in all appropriation states except Nevada, Oklahoma, and South Dakota. (57) In Nevada the restriction applies to all water rights; in the other two states it applies to irrigation rights only. The three states do provide, though, that water rights may be transferred if it becomes economically "impracticable" to continue using the water on the land.

Transferors can only transfer the rights they have. Their rights are measured not only by the quantity of water withdrawn, but the timing of withdrawals and the percentage of water withdrawn that is consumed. Thus, as mentioned earlier, a power company purchasing an irrigation water right may have to provide storage in order to consume water in nonirrigation seasons. If no storage on the stream exists, water in the nonirrigation seasons may be availabe for appropriation. If storage does exist, the utility can perhaps arrange to have its summer water consumptive right allocated on a prorata basis throughout the year.

Several states have recently adopted use change criteria which directly or indirectly affect the possibility of transferring water to cooling use. Only one state, California, has an important restriction.

As discussed in Chapter IV, California has a policy of not approving the use of fresh inland water for thermal power plant cooling. This restriction 
probably reflects, in part, efforts by the California Farm Bureau Federation to restrict the transfer of water from agricultural to industrial use. The California Federation has adopted the following resolution.

No. 47

\section{Electrical Power Generation}

"High quality fresh water in California is insufficient to meet anticipated demands for domestic, industrial, and food production purposes.

Water of a quality which makes it useful for agriculture and domestic consumption should be protected for those uses. cooling water for electric power generators should be supplied by sources in the following order of priority:

1. Ocean water

2. Waste water which would otherwise be discharged to the ocean.

3. Drainage water not suitable for agricultural, domestic, or industrial reuse.

Cooling tower vapor emissions may be detrimental to crops. Storage ponds for water supplies and blowdown disposal should displace a minimum of land capable of producing food."

The California Farm Bureau has opposed the use of Palo Verde outfall drain water for cooling at the Sundesert Plant of San Diego Gas and Electric. Their position is that the water is still sufficiently fresh that it can be used for further irrigation. Other state farm bureaus do not take the same position as the California Farm Bureau. Farm Bureau offices in Arizona, Utah, and Colorado contacted by the author all advocated no restrictions on water rights transfers. They did, not suprisingly, prefer free market transfers to condemnation.

Montana prohibits an appropriator of more than 15 cubic feet per second (cfs) from changing from an agricultural to an industrial use. (59) There is no restriction, though, on a utility accumulating water rights each of 
which is less than 15 cfs. Perhaps surprisingly, Montana has yet to receive an application to change a water right from agricultural to industrial use.

In Wyoming, the water right administrator may consider the economic consequences to the community and state which would result from the changed use and whether other sources of water are available for the new use.

The Nevada legislation (49) directing the State Engineer to consider the economic welfare of the state before approving water use changes for power production was mentioned earlier.

Legislation has been proposed in at least two states which would affect the transfer of water from agricultural to industrial use. H.B. 1110, introduced in the Colorado General Assembly in 1975, would have precluded a change of water rights out of irrigation use "if such change would diminish the amount of water available for irrigation purposes in the water division in which the water right is situated." The bill did not pass and has not been reintroduced. A.B. 222, introduced in the California Assembly on January 17, 1977, would preclude prime agricultural 1and from being used for other than agricultural use or compatible uses "which will not adversely affect the agricultural use of such land and for which there is no reasonable alternative location."

Transfer of water from agricultural use to industrial use does not necessarily have to result in less agricultural production. The U.S. General Accounting office (GAO) found that many farm lands are over-irrigated. (61) This causes reduced irrigation efficiency, limits crop production, increases farming costs, and contributes to water pollution. Two of the factors cited as contributing to over-irrigating were low water prices and the existing system of water rights. GAO found that when water cost increases, average irrigation efficiency also increases. It also observed that some farmers tend to over-irrigate because they fear losing

a/ Personal communication with Mr. Theodore J. Doney, Deputy Director, Montana Department of Natural Resources, February 28, 1977. 
their existing water quantity rights. In a given season they may also fear that future water supplies will be diminished and they they should therefore apply the water while they have it.

\section{Riparian System}

Water rights in riparian jurisdictions may also be sold and transferred. The transferee is subject to the same reasonable use restriction as the transferor. Eastern states with permit procedures do not generally have specific transfer procedures. It is probable that transfers would be approved to new purchasers for the same place and purpose of use, but that proposed transfers to new uses or places of use would be processed as applications for new permits. (62)

In many riparian jurisidictions water cannot be transported for private use on nonriparian land. The question of the extent of riparian lands has been litigated often in Eastern states. The general rule appears to be that riparian land is real property underlying or bordering the watercourse. Riparian land may extend away from the watercourse as long as it is under the same title and is in the same watershed.

There is little information available on the sale of riparian water rights separate from riparian 1 and. ${ }^{(54)}$ The deficiency may exist because water is relatively plentiful in riparian jurisdictions.

\section{Water Management Organizations}

In the areas of the West where wet/dry cooling is likely to be needed first, i.e., areas where water is fully appropriated and contracted, purchase of water entitlements from some type of water management organization is a likely source of water. In this case, the utility would not be obtaining a water right, because the actual appropriative right will be held by some other entity (e.g., the Water Management Organization or the Bureau of Reclamation). Water management companies exist in a variety of forms including: mutual water companies, mutual ditch companies, conservancy districts, and irrigation districts. Together they deliver the majority of the water in the west to the ultimate user. One source reports that in 
1964, mutual incorporated ditch companies and water conservancy districts delivered $68 \%$ of the total irrigation water to the user.

Transfer of water from water management organizations generally occurs with relatively little difficulty. In mutual water organizations, the purchaser negotiates with shareholders in the water management organization. Purchase of shares entitles him to a certain amount of water. Alternatively the utility may be able to simply purchase water entitlement contracts from owners in nonmutual organizations. This type of transfer is common in the Northern Colorado Water Conservancy District, for example.

Acquisition of water entitlements from water management organizations has several potential advantages for the purchaser. Since the purchaser is obtaining a contract right in water as opposed to a real property right, no legal proceeding before a court or state agency is required. There is somewhat more flexibility regarding the quantity of water purchased and the point of diversion. It is claimed that the return-flow consequences of transfer have little impact. (65) Finally, water management organizations often have storage capacity constructed which could enable a utility to obtain a year-round source of water.

GROUND WATER

The extent to which ground water can be used for future cooling is uncertain. Perhaps the chief obstacle to its use is the lack of certainty in future supplies. In many areas where future water pressures will be most severe, ground water is currently being mined, i.e., being withdrawn faster that it is being recharged. The quantity of water available must therefore decrease sometime in the future.

The quantity of underground water potentially available for use is large. The total amount of ground water in underground storage which is usable with present technology was reported by the National Water Commission to approximate 35 years' annual surface runoff -- or about 46 billion acreft. Between one-third and one-half of the conterminous U.S. is underlaid by ground water areas capable of yielding $50 \mathrm{gal} / \mathrm{min}$ or more to wells. 
To date, relatively little ground water has been withdrawn for power plant cooling. In 1970, it was estimated that 170,000 million gallons per day (mgd) were withdrawn in the U.S. for power plant cooling. Of this total, only $1300 \mathrm{mgd}$ represented ground water. ${ }^{(67)}$ of the $1300 \mathrm{mgd}, 850 \mathrm{mgd}$ were estimated to be withdrawn in only three states -- California, Minnesota, and Nebraska.

Geographic areas where the water table is declining rapidly include Nebraska, the Texas panhandle, eastern Colorado, and western Kansas. (68) Some geologists estimate that the Texas panhandle will run out of recoverable ground water within 25 years. ${ }^{(68)}$ The water table in western Kansas declined an average of 3.5 feet in 1976. ${ }^{(68)}$ California and Arizona have also experienced overdrafts.

Four ground water law systems exist in the U.S. ${ }^{(69)}$ In much of the East, Midwest, and Texas ground water law is judge-made law, derived from the English common law system. Each landowner is allowed to pump ground water under his land without limit. Many Eastern states do require pumping permits. Two modifications of the common law rule have appeared in the U.S. The reasonable use rule, analogous to the riparian system for surface waters, applies in Arizona. The correlative rights rule is similar to the reasonable use rule and applies in California and other Western states. Literally applied, the correlative rights doctrine allocates to each landowner overlying a ground water basin a share in proportion to his surface ownership.

The prior appropriation system applies in a majority of the western states. Most require permits to withdraw water. States having appropriation permit systems include Alaska, Kansas, Nevada, New Mexico, North Dakota, Oklahoma, Oregon, South Dakota, Utah, Washington, and Wyoming. Arizona, California, and Montana apply the appropriation system to particular areas.

The extent to which ground water mining is regulated varies from state to state. In California, the State Supreme Court established a rule requiring pro rate cutbacks in pumping when an aquifer is overdrawn. (70) 
The Orange County Water District in California has a comprehensive ground water management system which requires those pumping water to pay an assessment if they pump water in excess of what the District considers reasonable for the year. (71) Some western states, including Oregon, Wyoming, Nevada, Arizona, and New Mexico utilize a quota system which may exclude new pumpers from an aquifer. South Dakota and Idaho have statutes which prohibit the withdrawal of ground water in quantities which exceed natural recharge. Although ground water mining is detrimental to a utility by making future supplies uncertain, it could be partly advantageous because as the water table drops, agricultural users will likely abandon their rights when pumping costs exceed the value of the water to them.

In seeking to acquire ground water, a utility can purchase an existing pumping operation and use the water on the site or it can purchase water and transport it to a new location. Under the common law rule, the water can be transported away from the pumping point. Under the other ground water law systems, transfer outside the basin in which it is found may not be accepted if other users within the basin are injured. (72)

The G.E. (1) and HEDL ${ }^{(33)}$ studies considered the use of ground water in making their wet/dry cooling projections. It is difficult to generalize about how widely ground water will be used in the future because the variables affecting its use are so site specific. Use for particular plants will likely depend on whether an assured supply can be obtained and whether the locations with ground water available are consistent with other plant siting criteria. 


\section{LEGAL UNCERTAINTIES COMPLICATING THE ACQUISITION OF WATER}

A variety of legal uncertainties which can complicate the acquisition of water. Several sources of uncertainty, such as incomplete and inaccurate water rights records were identified in Chapter $V$. Three other elements of uncertainty are discussed in this chapter: Indian water rights, other Federal reserved rights, and preservation of instream water. This list is clearly not exhaustive.

INDIAN WATER RIGHTS

Indian water rights may be the most significant element of legal uncertainty facing the utility seeking water for cooling. Indian rights derive from the implied reservation doctrine which was first applied by the Supreme Court in the Winters case ${ }^{(73)}$ to an Indian reservation in Montana in 1908. The doctrine was later applied to other Federal reserved lands in Arizona v. California. ${ }^{(74)}$

The implied reservation doctrine can be stated in the following way. When the public lands, e.g., national forests and parks, and Indian reservations were set aside by the Congress for special use, there was reserved by implication for each conclave "enough of the then unappropriated water appurtenant to the lands reserved to effectuate whatever purpose the reserved lands were set aside to serve, and this constitutes a water right with a priority of the date the lands were reserved." (75) The doctrine has raised a host of unanswered questions among which are: How much water is reserved? Must the water be used on the reservation? Can the water be sold? What purposes can the water be used for? Does the purpose have to have been foreseeable when the land was reserved? These questions have only been partially answered, if at all.

In Arizona v. California, the Supreme Court detemined that five Indian reservations in Arizona, California, and Nevada were entitled to water priorities dating back to 1864 in the amount of about 1 million acre-ft annually. This represents about $15 \%$ of the water supply in the 
lower Colorado River Basin. This water is available for development, and could potentially displace existing water uses. Alternatively this water and other water reserved for Indian use may very well be available for purchase by utilities. No legislation specifically prohibits the sale of Indian water rights. Without the capital to fully exploit their water right, Indian tribes may be willing in some instances to sell their water.

The water allocation in Arizona v. California was based on irrigation requirements. For Indian reservations in areas without irrigation potential, the allocation may be based on other criteria, perhaps even energy development. (77) This possibility complicates further the question of how much water is within the scope of the reserved right.

OTHER FEDERAL RESERVED RIGHTS

Implied water reservations for public lands stem from the decision in Arizona v. California. The amount of water potentially affected by Federal reserved rights is large indeed. In the eleven conterminous western states, $59 \%$ of the total water yield flows from National Forest and National Park reservations. (78) Except for Indian water rights, however, the quantity of water involving Federal rights adjudicated under the reservation doctrine has been relatively sma11. As of 1972, Professor Charles Corker of the University of Washington Law School was able to find only one case where a water user exercising a valid state water right had been forced to surrender it to Forest Service use under the reservation doctrine. (79) Professor Corker also points out that the doctrine is not really needed by the Federal Government. It could obtain all the water it requires through exercise of eminent domain. Given the vast sums that have been spent in developing western water, the amount of money necessary to condenn needed water does not seem to be a compelling reason for the Federal government to rely on reserved rights rather than eminent domain.

A recent Supreme Court case, Cappaert v. United States, $(80)$ has extended the Federal reserved rights doctrine to ground water. The suit was brought by the U.S. to preserve the water level in Devil's Hole, a limestone cavern in Nevada, which is a detached componet of Death Valley 
National Monument. The defendants pumped ground water outside the monument for irrigation. The pumping, however, lowered the water level in the cavern and endangered a unique species of desert fish called pupfish. The Supreme Court affirmed the lower court decision which permanently enjoined pumping that would lower the water level sufficiently to endanger the fish. The most significant aspect of the case may be its potential precedent value in establishing ground water rights for Indian reservations. Ground water pumping often requires lower capital expenditure than surface water diversion systems. Indians with ground water access may therefore be more inclined to initiate irrigation, to the possible detriment of other ground water users.

\section{PRESERVATION OF INSTREAM WATER}

In recent years there has been a trend toward preservation of instream water for aesthetic, recreation, and fish and wildlife purposes. The trend has occurred at both the Federal and state level.

The principal Federal involvement originated with passage of the National Wild and Scenic Rivers Act of 1968. ${ }^{(81)}$ Section 7 (A) of the Act provides that no Federal agency may assist by loan, grant, license, or otherwise in the construction of a water resources project which would have a direct and adverse effect on the natural river values as determined by the management agency. For practical purposes, the Act probably precludes the consumptive use of water for power plant cooling from stretches of rivers within the Wild and Scenic Rivers system. Water projects above or below the protected area may be acceptable if the administering U.S. agency determines that the project does not have an unreasonable impact. The rivers currently in the Wild and Scenic River System are shown in Table 8.

A number of states including California, Colorado, Idaho, Maine, Michigan, Montana, Oklahoma, Oregon, Utah, Wisconsin, and Wyoming have also taken legislative and/or administrative steps to preserve instream water. The power of the state to accomplish the preservations has usually been upheld, and in some cases even extended, by the state courts. 


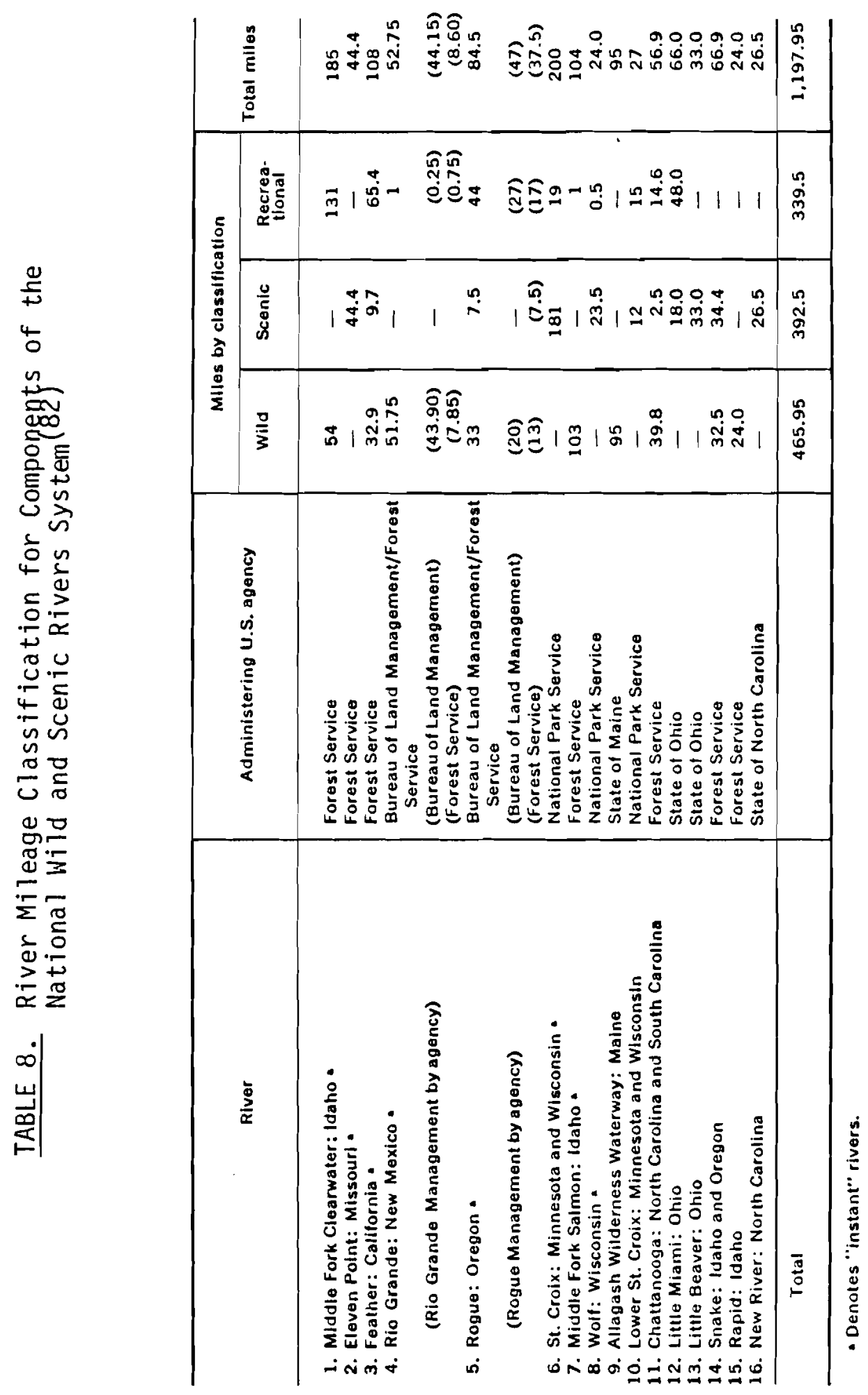




\section{ACKNOWLEDGMENTS}

This report contains an account of the work sponsored by the Division of Nuclear Research and Applications of ERDA under the Dry Cooling Tower Project at Battelle, Pacific Northwest Laboratory (PNL). The project was completed under the direction of I. Helms, Project Officer; W. F. Savage, Manager of Advanced Concepts Evaluation Branch, ERDA Division of Nuclear Research and Applications; and B. M. Johnson, Manager of the Dry Cooling Tower Project at PNL.

The following personnel at PNL made valuable critiques of this work: R. T. Allemann, J.W. Currie, B. M. Johnson, and J. C. King. Betsy Owzarski edited the final draft. 


\section{REFERENCES}

1. General Electric Company, San Jose, CA, Future Needs for Dry or Peak Shaved Dry/Wet Cooling and Significance to Nuclear Power Plants, EPRI NP-150, prepared for the Electric Power Research Institute, Palo Alto, CA, February 1976.

2. U.S. Energy Research and Development Administration, A National Plan for Energy Research Development and Demonstration, ERDA-48, Vol. 1, June 1975.

3. Espey, Huston, and Associates, Inc., Consumptive Use Implications of the Proposed EPA Effluent Guidelines for Steam-Electric Power Generation, May 31, 1974, included in Edison Electric Institute Utility water Act Group (UWAG) comments on EPA's Proposed $\$ 304$ Guidelines and $\$ 306$ Standards of Performance for Steam Electric Power Plants, June 26, 1974.

4. B. J. Bond and P. L. Russ, "TVA Uses of Waste Heat in Agricultural Production", Tennessee Valley Authority, Muscle Shoals, AL, June 1976.

See also, E. F. Gloyna, H. H. Woodson and H. R. Drew, editors, Water Management by the Electric Power Industry, University of Texas at Austin Center for Research in Water Resources, Section Five, 1975.

5. R. J. Huston, "An Overview of Water Requirements for Electric Power Generation", in Gloyna, et al., editors, Ibid.

6. Reference 1, p. 3-3.

7. FWPCA, Section 101 (a) (11), 33 U.S.C., \$1251 (a) (1).

8. FWPCA, Section 502 (6), 33 U.S.C., \$1362 (6).

9. FWPCA, Section 316, 33 U.S.C., §1326.

10. 40 CFR $\$ 423.11$ (d), $423.13(1),(m)$.

11. 40 CFR $\$ 423.15$ (1), 423.25 (1).

12. 575 F.2d 1351, 9 ERC 1033 (1976).

13. 40 CFR $\$ 423.13$ (1) (3), \$423.15 (1) (2).

14. 40 CFR $\$ 423.15$ (1), 40 CFR, $\$ 423$ (1).

15. 41 Federal Register 12694, March 26, 1976.

16. United Engineers and Constructors, Inc., Philadelphia, PA, Engineering and Economic Evaluation of Wet/Dry Cooling Towers for Water Conservation, UE\&C-ERDA-761130, p. 5-8, November 1976. 
17. Iowa Institute of Hydraulic Research, Analysis of Different Types of Dry-Wet Cooling Towers, National Technical Information Service (NITS) No. PB-261-315, Ju1y 1976.

18. R. L. Dewsnup, "Assembling Water Rights for a New Use: Needed Reforms in the Law", 17 Rocky Mountain Mineral Law Institute 613, 623, Matthew Bender \& Co., New York, NY, 1972.

19. Northern Great Plains Resources Program, Effects of Coal Development in the Northern Great Plains, Denver Federal Center, Denver, CO, Apri1 1975.

20. Gloyna, op. cit, Reference 4,

See also, "Treated Sewage for Power Plant Makeup Water", 76 Power Engineering 40, November 1972.

21. U. S. Nuclear Regulatory Commission, Final Environmental Statement for Palo Verde Nuclear Generating Station, Units 1, 2, and 3, NUREG75/078, p. 9-15, September 1975.

22. John R. Teerink, Bookman-Edmonston Engineering, Inc., The Impact of Power Plant Siting on California's Water Resources, prepared for the Association of California Water Agencies, Sacramento, CA, p. 32, July 1976.

23. Kaiser Engineers, Economic Study of the Use of Agricultural Waste Water for Power Plant Cooling Water Makeup, prepared for the Electric Power Research Institute, January 1977.

24. Irrigation districts of ten construct storage capacity in order to increase the volume of water available for summer irrigation. See Reference 18.

25. Victor E. Gleason, "Water Projects Go Underground", 5 Ecology Law Quarterly 625, 1976.

26. Robert A. Young and S. Lee Gray, Economic Value of Water: Concepts and Empirical Estimates, NTIS, No. PB-210-356, p. 308, March 1972.

27. Maurice M. Kelso, et al., Water Supplies and Economic Growth in an Arid Environment, an Arizona Case Study, The University of Arizona Press, 1973. Cited in Reference 21.

28. Time, March 7, 1977, p. 79.

29. Allen V. Kneese and F. Lee Brown, "Water Demands for Energy Development", 8 Natural Resources Lawyer 311, 1975.

30. C. R. Murray and E. B. Reeves, Estimated Use of Water in the U.S. in 1970, U.S. Geological Survey Circular 676, p. 17, 1972。 
31. U.S. Department of the Interior, Westwide Study Report on Critical Water Problems Facing the Eleven Western States, P. 75, April 1975.

32. Ref. 30 , op cit, Table 7.

33. D. E. Peterson, J. C. Sonnichsen, Hanford Engineering Development Laboratory, Richland, WA, Assessment of Requirements for Dry Towers, HELD-TME 76-82, prepared for the U.S. Energy Research and Development Administration, September 1976.

34. The water situation in Pennsylvania is discussed in R. T. Weston and J. R. Gray, "Legal Control of Consumptive Water Use in Pennsylvania Power Plants," 80 Dickinson Law Review 354, Spring 1976.

35. Water for Energy Management Team, U.S. Department of the Interior, Report on Water for Energy in the Upper Colorado River Basin, July 1974.

36. Water for Energy Management Team, U.S. Department of the Interior, Report on Water for Energy in the Northern Great Plains Area with Emphasis on the Yellowstone River Basin, P. VII-1, January 1975.

37. Water Resources Division, Montana Department of Natural Resources and Conservation, The Future of the Yellowstone River.....?, January 1977.

38. Montana Revised Codes Annotated, §89-8-103, Environment Reporter, p. 1784, March 18, 1977.

39. Ref. 19, p. 80 .

40. California State Resources Control Board, Sacramento, CA, "Water Quality Control Policy in the Use and Disposal of Inland Waters Used for Power Plant Cooling", June 19, 1975.

41. California Energy Resources Conservation and Development Administration, Electricity Forecasting and Planning Report, p. VI-31, September 1976 .

42. Ibid, P. VI-36.

43. Ibid, P. VI-38.

44. Ref. 22 , op cit, p. 31 .

45. Richard L. Dewsnup and Dallin W. Jensen, editors, A Summary - Digest of State Water Laws, prepared for the National Water Commission, U.S. Government Printing Office, 1973. 
46. Alaska Statutes $\$ 46.16 .080$.

47. California Water Code \$1253-1258.

48. Oregon Revised Statutes $\$ 537.170$.

49. Nevada Revised Statutes $\$ 533.370$.

50. Session Laws, Chapter 275 (1975).

51. Richard L. Dewsnup, "Problems Under State Water Laws: Initiation of New Rights", 8 Natural Resources Lawyer 347 (1975).

52. Environmental Defense Fund, Inc. V. Morton, 420 F. Supp 1037 (1976).

See also, George W. Pring and Laurence Edelman, "Reclamation Law Constraints on Energy/Industrial Uses of Western Water," 8 Natural Resources Lawyer 297 (1975).

53. Frank J. Trelease, Water Law: Resource Use and Environmental Protection, West Publishing Co., St. Paul, MN, p. 735, 1974.

54. Charles Meyers and Richard A. Posner, Market Transfers of Water Rights: Toward an Improved Market in Water Resources, NTIS No. PB-202620, Ju1y 1971 .

55. National Water Commission, Water Policies for the Future, U.S. Government Printing Office, June 1973.

56. Frank J. Trelease, "Changes and Transfers of Water Rights," 13 Rocky Mountain Mineral Law Institute 507, Matthew Bender \& Co., . 1967.

57. Ref. 53, op cit., p. 215.

58. California Farm Bureau Federation, Farm Bureau Policies 1977, Sacramento, CA.

59. Montana Revised Codes Annotated 589-892 (3).

60. Wyoming Statutes $\$ 41-4.1$.

61. U.S. General Accounting Office, "Better Federal Coordination Needed to Promote More Efficient Farm Irrigation", B-114885, June 22, 1976.

62. Ref. 45, op cit., p. 39.

63. L. M. Hartman and Don Seastone, Water Transfers: Economic Efficiency and Alternative Institutions, Johns Hopkins Press, Baltimore, MD, p. $35,1970$. 
64. See References 18 and 63.

65. Ref. 54, op cit., p. 35.

66. Ref. 55, op cit., p. 230

67. Ref. 30 , op cit., p. 27.

68. The Wal1 Street Journal, May 31,1977, p. 1, col. 8.

69. Robert Emmet Clark, "Ground Water Law: Problem Areas", 8 Natural Resources Lawyer 377, 1975.

70. Pasadena V. Alhambra, 207 P.2d 17 (1949).

71. Ref. 55, op cit., p. 235.

72. See 78 American Jurisprudence Second Edition, p. 610.

73. Winters V. United States, 207 U.S. 564 (1908).

74. Arizona v. California, 373 U.S. 546 (1963).

75. Charles E. Corker, "Federal-State Relations in Water Rights Adjudication and Administration", 17 Rocky Mountain Mineral Law Institute 582, Matthew Bender \& Co., 1972.

76. Monroe E. Price and Gary D. Weathorford, "Indian Water Rights in Theory and Practice: Navajo Experience in the Colorado River Basin", 40 Law and Contemporary Problems 104, Duke University School of Law, Winter 1976.

77. Frank J. Trelease, Federal-State Relations in the Law of Water Rights, NTIS No. PB-203-600, P. 162-166, 1971.

78. Public Land Law Review Commission, One Third of the Nation's Land 141, U.S. Government Printing Office, 1970.

79. Ref. 75, op cit., p. 586.

80. Cappaert v. United States, 96 S.Ct. 2062 (1976).

81. 16 U.S.C. $\$ 1271-87$.

82. Environmental Quality--1976, The Seventh Annual Report of the Counci1 on Environmental Quality, U.S. Government Printing Office, Stock No. 041-010-00031-2, p. 96, September 1976.

83. A. Dan Tarlock, "Recent Developments in the Recognition of Instream Uses in Western Water Law", 1975 Utah Law Review 871, Winter 1975. 


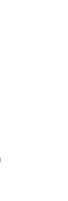




\section{DISTRIBUTION}

No. of

Copies

OFFSITE

A. A. Churm

Chicago Patent Group

Energy Research and

Development Administration

9800 South Cass Avenue

Argonne, IL 60439

Office of Assistant General

Counsel for Patents

Energy Research and

Development Administration

Washington, DC 20545

27 ERDA Technical Information Center

10 I. Helms

Advanced Concepts Evaluation Branch - F-309

ERDA Division of Nuclear Research and Application Washington, DC 20545

W. F. Savage

Chief, Advanced Concepts Evaluation Branch

ERDA Division of Nuclear Research and Application Washington, DC 20545

D. C. Bauer

Director, Division of Nuclear Research and Application

Energy Research and Development Administration

Washington, DC 20545

W. E. Mott

Director, Energy Control Technology

ERDA Division of Biomedical and

Environmental Research

Washington, DC 20545
No. of

Copies

B. R. Dickey

Allied Chemical Company

550 2nd Street

Idaho Falls, ID 83401

J. S. Joyce

Allis-Chalmers Power Systems, Inc.

1135 South 70th Street

West Al1is, WI 53214

E. T. Wanderer

Aluminum Company of America

Alcoa Technical Center

ATcoa Center, OH 45069

H. J. Janzon

American Electric Power

2 Broadway

New York, NY 10004

T. Woods

Arizona Public Service Co.

2121 W. Cheryl Drive

Phoenix, AZ 85021

M. W. Peterson

Babcock \& Wilcox

Fossil Power Division

20 South Van Buren

Barberton, $\mathrm{OH} 44203$

G. C. Cree 1

Baltimore Gas \& Electric Co. Gas \& Electric BuiTding

Baltimore, MD 21203

E. Schinner

Baltimore Aircoil Co., Inc.

P.0. Box 7322

Baltimore, MD 21227 
No. of

Copies

J. P. Budliger

Battelle-Geneva

7 Route De Drizi

1227 Geneva, SWITZERLAND

P. Leung

Bechtel Corporation

P.0. Box 60860

Terminal Annex

Los Angeles, CA 90060

G. R. Retti

Bechtel Corporation

P.0. Box 3965

San Francisco, CA 94119

J. P. Rossie

R. W. Beck and Associates

400 Prudential Plaza

Denver, CO 80202

B. Westre

Black Hills Power and Light Company

P.0. Box 1400

Rapid City, SD 57701

L. E. Stamets

California State Energy Resources Conservation and Development Commission

1111 Howe Avenue

Sacramento, CA 95825

J. Sel1

Carolina Power \& Light Co.

336 Fayettesville Street

Raleigh, NC 27602

J. Morse

Catalytic Construction Corp.

P.0. Box 11402

Charlotte, NC 28029
No. of

Copies

H. H. Osborn

Combustion Engineering

Air Preheater Company

Wellsville, NY 14895

R. H. Holyoak

Commonwealth Edison

One First Plaza

P.0. Box 767

Chicago, IL 60690

C. L. Newman

Consolidated Edison Co. of New York, Inc.

4 Irving Place

New York, NY 10003

W. A. Messner

Consolidated Edison Co. of New York, Inc.

4 Irving Place

New York, NY 10003

F. K. Moore Corne 11 University Ithaca, NY 14850

R. J. Haberski

Curtiss-Wright Corp.

One Passaic Street

Wood Ridge, NJ 07075

S. K. BlackTey

Duke Power Company

P. 0. Box 2178

Charlotte, NC 28201

E. Guyer

Dynatech Company

99 Erie Street

Cambridge, MA 02139 
3. K. Swindt

Ecodyne Cooling Products Co.

San Rosa, CA 95403

J. Maulbetsch

Electric Power Research Institute

3412 Hillview Avenue

P.0. Box 10412

Palo Alto, CA 94304

L. Geller

Empire State Electric Energy Research Corp.

1250 Broadway

New York, NY 10001

M. Maxwe11 (MD-61)

IERL-RTP

Environmental Protection Agency

Research Triangle Park, NC 27711

F. H. Rainwater

Environmental Protection Agency

Pacific Northwest Water Laboratory

200 S.W. 35th Street

Corvallis, OR 97330

W. Hoydisch

Environmental Sciences and Services

44-43 37th Street

Long Island City, NY 11101

E. L. Damon

Fostor Wheeler Energy Co.

$110 \mathrm{~S}$. Orange Avenue

Livingston, $\mathrm{NJ} 07039$

A. M. Rubin

Frank 1 in Institute

Twentieth \& Parkway

Philadelphia, PA 19103
B. Davis

GEA Airexchangers, Inc.

46 Worthington Drive

Maryland Heights, MD

63043

A. C. Eulberg

General Atomic

P.0. Box 81608

San Diego, CA 92138

E. H. Miller

General Electric Co.

Large Steam Turbine Division

300 Nott Street

Schenectady, NY 12301

R. K. Shah

Harrison Radiator Division

Genera1 Motors Corp.

Lockport, NY 14094

J. F. Sebald

Gilbert Associates, Inc.

525 Lancaster Avenue

Reading, PA 19603

J. E. Taboric

Heat Transfer Research Inc.

1000 S. Fremont Avenue

Alhambra, CA 91802

E. C. Smith

Hudson Products

6855 Horwin Drive

Houston, TX 77036

M. W. Larinoff

Hudson Products

6855 Horwin Drive

Houston, TX 77036

W. R. Scott, Jr.

Ingersoll-Rand

Philtipsburg, NJ 08865 
No. of

Copies

C. Rocco

Italimpianti - Societa Italiana Impianti p.a.

Piazza, Piccapietra 9

18121 Genoa, ITALY

J. L. Mulloy

Los Angeles Department of Water and Power

111 N. Hope Street

Los Angeles, CA 90012

R. J. Meyer

Louisiana Power \& Light Co.

142 Delaronde Street

New Orleans, LA 70174

E. S. Miliaras

The Charles T. Main Co.

Southeast Tower

Prudential Center

Boston, MA 02199

R. Landon

Marley Co.

5800 Fox Ridge Drive

Mission, KS 66202

L. R. GTicksman

Massachusetts Institute of Technology

77 Massachusetts Avenue

Cambridge, MA 02139

M. W. Golay

Massachusetts Institute of Technology

77 Massachusetts Avenue

Cambridge, MA 02139

R. Harleman

Department of Civil Engineering

Massachusetts Institute of

Technology

77 Massachusetts Avenue

Cambridge, MA 02139
No. of

Copies

A. J. Vander Weyden

McDonnel Douglas Astronautics Co. 5301 Bols Avenue

Huntington Beach, CA 92647

R. Hofacher

Montana Power Co.

40 E. Broadway

Butte, MT 59701

W. G. Hoydysn

New York University

University Heights

New York, NY 10453

W. Kals

Niagara Blower

405 Lexington Avenue

New York, NY 10017

R. H. Meyer

Northeast Utilities

P.0. Box 270

Hartford, CT 06101

L. P. Davis

Department of Mechanical Engineering

Oregon State Inniversity

Corvatiis, OR 97330

C. E. Wicks

Department of Chemical

Engineering

Oregon State University

Corvallis, OR 97330

J. G. Knudson

Engineering Experiment Station

Oregon State University

Corvallis, OR 97330

J. W. Miche 1

OTEC Heat Exchange Project Activity

Oak Ridge National Laboratory

Box Y

Oak Ridge, TN 37830 
No. of

Copies

A. A. Ariey

Pacific Gas \& Electric

77 Beale Street

San Francisco, CA 94106

F. F. Mautz

Pacific Gas \& Electric

77 Beale Street

San Francisco, CA 94706

$P$. G. Humphries

Pacific Power \& Light Co.

Public Service B1dg.

Portland, OR 97204

D. G. Pfeiffer

Pennsylvania Power \& Light

2 North Ninth Street

Allentown, PA 18101

T. Rozenmann

PFR Engineering Systems, Inc.

Suite 832

4676 Admiralty Way

Marina del Rey, CA 90291

Prof. Ing. Carlo Roma

Piazza delle Muse 8

Rome, ITALY

G. L. Henderson

Power Generation Cooling Sys tems

4714 - 52nd Street S.

Seattle, WA 98118

R. F. Walker

Public Service of Colorado

5900 E. 39th Avenue

Denver, CO 80207

J. D. Maddox

Public Service of New Mexico Corporate Planning Dept.

Albuquerque, NM 87103
No. of

Copies

G. E. Collins

Research Cottrel1

Hamon Cooling Tower Division

Box 750

Bound Brook, NJ 08805

R. Lindberg

Reynolds Aluminum Co.

Reynolds Metallurgical

Research Laboratory

Richmond, VA 23261

R. G. Lacy

San Diego Gas \& Electric

101 Ash Street

San Diego, CA 92107

R. L. Skone

Seattle City Light

1015 Third Ave.

Seattle, WA 98104

F. A. McCracken

Southern California Edison 2244 Walnut Grove Avenue

Rosemead, CA 91770

P. Sporn

Consultant Engineer

74 Trinity P1., Suite 511

New York, NY 10006

A. L. London

Department of Mechanical

Engineering

Stanford University

Stanford, CA 94305

J. Y. Parce

Stearns and Rogers

700 S. Ash Street

Denver, CO 80222

D. H. Guild

Stone \& Webster Engineering Corp.

225 Franklin Street

Boston, MA 02107 
No. of

Copies

H. I. Wilson

Tampa Electric Co.

P.0. Box 111

Tampa, FL 33601

W. Keel

Texas Electric Service Co.

$115 \mathrm{~W}$. Seventh Street

Fort Worth, TX 76102

A. A. Ward

Tucson Gas \& Electric

220 W. 6th Street

Tucson, AZ 85701

J. Bartz

Union Carbide Corp.

Linde Division

61 East Park Drive

Tonawanda, NY 14150

G. J. Kidd

Union Carbide Corp.

ORGDP - K-25

P.0. Box D

Oak Ridge, TN 37803

F. Notaro

Union Carbide Corp.

Linde Division

61 East Park Drive

Tonawanda, NY 14150

G. A. Englesson

United Engineers \&

Constructors

1401 Arch Street

Philadelphia, PA 19105

K. Simhan

University of Bremen

Bremen, WEST GERMANY

J. F. Kennedy

University of Iowa

Hydraulic Research Institute

Iowa City, IA 52240
No. of

Copies

J. H. Hutchinson

Utah Power \& Light

1407 W. N. Temple

Salt Lake City, UT 84103

S. Ragone

Virginia Electric \& Power Co.

700 E. Franklin Street

Richmond, VA 23261

J. T. Kimball

Washington State University

College of Engineering

Pullman, WA 99163

D. L. 01son

Washington Water Power Co.

E. 1411 Mission Avenue

Spokane, WA 99202

G. H. Soule

West Associates

Sierra Pacific Power Co.

100 E. Moana Lane

Reno, NV 89510

J. A. Barnett

Executive Director

Western States Water Council

220 South 2nd East

Suite 200

Salt Lake City, UT 84111

G. J. Silvestri

Westinghouse Electric Corp.

Steam Turbines Division

Lester Branch

Box 9175

Philadelphia, PA 19113

K. A. 0leson

Westinghouse Electric Corp.

Steam Turbines Division

Lester Branch

Box 9175

Philadelphia, PA 19113 
No. of

Copies

L. E. Wilkinson

Consultant

6582 Ganon Street, S.E.

Salem, OR 97301

ONSITE

ERDA Richland Operations Office Energy Programs Division

H. E. Ransom

Westinghouse Hanford Company Hanford Engineering Development Laboratory

J. Fletcher

99 Battelle-Northwest

R. T. Allemann

D. J. Braun

D. J. Braun

J. B. Burnham

N. E. Carter

J. W. Currie

D. E. Deonigi

R. L. Dillon

D. W. Dragnich

R. L. Drake

D. W. Faletti

J. W. Finnigan

T. J. Foley

J. C. Fox

J. J. Hauth

A. J. Haverfield

C. H. Henager

P. L. Hendrickson (20)

D. L. Hesse?

A. B. Johnson

W. S. Kelly

R. S. Kemper

C. J. Knoll
No. of

Copies 


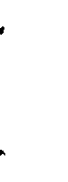

